\title{
The role of selenium in thyroid gland pathophysiology
}

\author{
Michat Stuss, ${ }^{1,2}$, Marta Michalska-Kasiczak', Ewa Sewerynek1,2 \\ ${ }^{1}$ Department of Endocrine Disorders and Bone Metabolism, Chair of Endocrinology, Medical University of Lodz, Poland \\ ${ }^{2}$ The Outpatient Clinic of Endocrinology and Osteoporosis Therapy of the Regional Centre of Menopause and Osteoporosis of the \\ Military Teaching Hospital in Lodz, Poland
}

\section{Disclosure of conflicts of interest}

All authors certify that they have no financial interests such as employment, stock ownership, honoraria, or paid expert testimony, as well as any personal relationships, academic competition, and intellectual passion, which may inappropriately influence their actions. All funding sources supporting the work and all institutional or corporate affiliations are acknowledged in a footnote.

All authors have had full access to all the data in the study (if applicable) and thereby accept full responsibility for the integrity of the data and the accuracy of the data analysis.

\begin{abstract}
It is now assumed that proper functioning of the thyroid gland (TG), beside iodine, requires also a number of elements, including selenium, iron, zinc, copper, and calcium. In many cases, only an adequate supply of one of these microelements (e.g. iodine) may reveal symptoms resulting from deficits of other microelements (e.g. iron or selenium).

Selenium is accounted to the trace elements of key importance for homeostasis of the human system, in particular, for the proper functioning of the immune system and the TG. Results of epidemiological studies have demonstrated that selenium deficit may affect as many as one billion people in many countries all over the world. A proper sequence of particular supplementations is also worth emphasising for the significant correlations among the supplemented microelements. For example, it has been demonstrated that an excessive supplementation of selenium may enhance the effects of iodine deficit in endemic regions, while proper supplementation of selenium in studied animals may alleviate the consequences of iodine excess, preventing destructive-inflammatory lesions in the TG.

This paper is a summary of the current knowledge on the role of selenium in the functionality of the TG. (Endokrynol Pol 2017; 68 (4): 440-454)

Key words: selenium, thyroid gland, supplementation
\end{abstract}

\section{Introduction}

Selenium is accounted to the trace elements of key importance for homeostasis of the human system, in particular, for the proper functioning of the immune system $[1,2]$. Results of epidemiological studies have demonstrated that selenium deficit may affect as many as one billion people in many countries all over the world [3].

\section{Selenium doses and sources}

Following the recommendations of the World Health Organisation (WHO), supplementation of this microelement should not exceed $70 \mu \mathrm{g} /$ day, while its daily intake above $400-700 \mu \mathrm{g}$ may exert toxic effects [4]. Following the guidelines developed by the Food and Nutrition Board of the National Academy of Science, men should consume 40-70 $\mu \mathrm{g}$ and women 45-55 $\mu \mathrm{g}$ (60-70 $\mu \mathrm{g}$ during gestation and lactation periods) daily
$[5,6]$. According to population studies, the mean daily intake of selenium at European countries is $20-70 \mu \mathrm{g}$ $[1,5,7-9]$ and $20-59 \mu \mathrm{g}$ in Poland [10, 11]. In turn, following the 30-day observation of other researchers, a typical diet of an average American provides from 90 to $168 \mu \mathrm{g}$ of this microelement daily [12]. It is estimated that, in some regions of China, selenium consumption reaches the level of $5 \mathrm{mg} /$ day $[10,13]$. In order to ensure an adequately broad safety margin, in some sources, we may come across the term reference selenium dose (RSD). According to Patterson and Levander the RSD is $350 \mu \mathrm{g} /$ day, which corresponds to the supplementation level of approximately $5 \mu \mathrm{g} / \mathrm{kg}$ of human body weight. According to the authors' assumption, the daily dose of $150 \mu \mathrm{g}$ should be delivered with food, while the remaining $200 \mu \mathrm{g}$ may be provided by supplements [14].

Thus, considering the application of selenium supplementation, one should be aware of its narrow therapeutic index and of the possibility of adverse effects, not only when diet supplements are used but 
also when selenium-rich foodstuffs are consumed [15]. It has been demonstrated that consumption of large volumes of fruit from certain plants, including, among others, the species of Lecythis ollaria, may cause hair loss, nausea, vomiting, and diarrhoea [16]. The selenium content may differ in the same foodstuffs but originating from different regions, which is associated with the climate, the volumes of this microelement in soil, and the ability of plants to accumulate it, which is directly translated into higher links of the food chains [17]. A high selenium content is, among others, characteristic for protein-rich foods, nuts, in particular Brazil nuts (more than $6 \mu \mathrm{g} / \mathrm{g}$ of the product), and fungi, including mushrooms and yeasts (selenium content in the latter amounts to as much as $3 \mathrm{mg} / \mathrm{g}$ ). As a rule, fruits and vegetables contain small volumes of this microelement (often below $0.5 \mu \mathrm{g} / \mathrm{g}$ of the product), which is associated with the high water content and low protein content. However, some of them may be good sources of selenium - among others, garlic, broccoli, cabbage, cauliflower, and kohlrabi [5].

Selenium, in its natural substance, most often takes an organic form of selenomethionine, methylselenocysteine, or $\gamma$-glutamylmethylselenocysteine. In turn, enriched products and supplements, beside organic compounds (selenoamino acids), often contain inorganic salts, especially of selenium (IV) [18]. It is assumed that organic selenium is more easily digestible, while yeasts provide an excellent substrate for production of its supplements [19]. It has been demonstrated that, on average, $85-95 \%$ of the dose of organic selenium compounds undergo intestinal absorption, while it is only $10 \%$ in the case of inorganic compounds. After it permeates into blood, selenium binds to erythrocytes and to globulins and albumins in plasma, being, later on, transported in this way to various tissues and organs. Its highest volumes are found in the liver, the kidneys, the testes, the thyroid gland (TG), the pancreas, and in the pituitary also in the hair and nails. The muscles are characterised by the highest selenium content (there may even be a half of the systemic selenium stock). It is possible to evaluate the degree of selenium supply to the organism by assaying the concentrations of these microelement-containing proteins, including, among others, P1 selenoproteins (SPP1) or glutathione peroxidase. Taking into account the significant role of selenoproteins in maintaining systemic homeostasis, it is recommended that the concentrations of these proteins are as high as possible. It has been determined that glutathione peroxidase 3 achieves the plateau status at concentration of approximately $125 \mu \mathrm{U} / \mathrm{L}$, which reflects selenium concentration in serum at approximately $1 \mu \mathrm{M} / \mathrm{L}$ (approximately $79 \mu \mathrm{g} / \mathrm{L}$ ), which, in turn, is ensured by the mean daily supplementation of $125 \mu \mathrm{g}$ of this microelement [20-24]. The highest concentrations of $\mathrm{P}$ selenoprotein were obtained at serum selenium levels from 110 to $125 \mu \mathrm{g} / \mathrm{L}$ [25]. In the literature, one may come across various reference ranges of selenium concentration in serum, depending on the geographic region, the country, as well as the ethnic group, which is related to diet.

\section{The issue of selenium deficit}

The effects of selenium deficit may be observed in the geographic regions with low selenium soils, such as Siberia and a major part of China [16, 26, 27]. The symptoms of selenium deficit concern many organs and systems and are manifested by decreased activities, as well as by impaired functions and structures that are associated with this microelement, i.e. the so-called selenoproteins [28]. The adverse effects caused by selenium deficit and most frequently described in literature include dilated cardiomyopathy (Keshan disease) and endemic osteoarthropathy (Kashin-Beck disease) [28-30].

The incidence of Keshan disease is highest in women of reproductive age and in children aged up to 10 years [30]. In turn, Kashin-Beck disease is characterised by changes that resemble rheumatoid arthritis, including shortening of fingers and toes and growing disturbances. Enhanced oxidative processes bring about lesions and necrosis of cartilages and cause bone deformations. The disease affects most often children aged up to 13 years $[7,29]$. Iodine deficit contributes to the occurrence/ /enhancement of Kashin-Beck disease symptoms [29, 31].

The following other significant effects of selenium deficit are worth mentioning: heart failure, arrhythmia, strokes, sudden infant death syndrome, infertility in men, prostate cancer, nephropathy, and exacerbation of symptoms of diseases, both associated with the immune system and autoimmunological; among others, thyroid disease [26, 32-34].

\section{The issue of selenium excess}

Analogously to selenium deficit, also its excess is most often observed in geographic areas with high-selenium content in soil; among others, in certain regions of India.

High selenium doses induce an excessive production of free radicals, causing DNA damage. In addition, selenium excess inactivates the proteins that are responsible for repair of damaged DNA, demonstrating high affinity to their thiol groups [35].

Excessive consumption of selenium causes classical symptoms of intoxication: systemic weakness, nausea, vomiting, and diarrhoea; moreover, neurological disorders may occur, e.g. ataxia $[7,36]$. Chronically increased selenium supplementation induces a medical condition called selenosis, which is manifested by: liver damage, 
haematopoiesis disorders, hair loss, infertility, rash, nail fractures, and an unpleasant (resembling garlic) mouth odour, as well as various neurological disorders [7, 27, 37]. The negative consequences of selenium excess on the endocrine system should also be mentioned, including an impaired synthesis of thyroid hormones $(\mathrm{TH})$, growth hormone, and insulin-like growth factor-1 (IGF-1) [7]. It has also been demonstrated that its excessive supplementation may increase the risk for diabetes mellitus of type 2 [38]. Moreover, inhalation of selenium compounds may contribute to the occurrence of chemical bronchitis and pneumonia (even pulmonary oedema), eye irritation, and headaches. The clinical data on doses that may cause adverse effects are rather inconclusive. It was shown in a study of the Chinese population that an increased incidence of selenosis is associated with doses of this microelement above $850 \mu \mathrm{g} /$ day [26]. In turn, regarding patients with rheumatoid arthritis, daily supplementation with $600 \mu \mathrm{g}$ of selenium from yeasts reduced arthritic pain but without any symptoms of intoxication with selenium [39]. In another study, patients receiving a daily dose of selenium of $700 \mu \mathrm{g}$ tolerated it very well [40]. In the opinion of many authors, the major benefits from selenium supplementation are observed in persons with a decreased supplementation rate of this microelement. In other cases, one should take under consideration an increased risk of the occurrence of metabolic disorders [38, 41].

\section{How selenium works}

As already mentioned, selenium atoms are part of the so-called selenoproteins and antioxidative enzymes, including, among others: glutathione peroxidases (GPs), thioredoxin reductases (TRRs), iodothyronine deiodinases (DIOs), selenoprotein P1 (SPP1), and selenoprotein W. GP was the first described selenoprotein; however, eight isoforms of the enzyme have so far been identified, depending on their structure and localisation [42]. The main task of GP is the protection of lipid membranes against oxidative stress. They catalyse the reactions of hydrogen peroxide $\left(\mathrm{H}_{2} \mathrm{O}_{2}\right)$ reduction and of organic peroxide $(\mathrm{ROOH})$ reduction, with production of selenous acid, as an intermediate product, or of some appropriate alcohols [33].

Three types of DIOs are distinguished. They play a key role in the activation of the other forms of TH to the most active triiodothyronine (T3) (type 1 and 2) and, in addition, in the inactivation of thyroxin and T3 (type 3) [43-46]. The above-mentioned group of enzymes plays then a key role in the proper functioning of the TG, as well as in its development [47]. In the case of selenium deficit, iodine metabolism is impaired, which supports various disorders in the synthesis of TH. It may have some impact on the clinical state and the general wellbeing of affected patients [34].

TRRs are biochemically responsible for the reaction of oxidised thioredoxin reduction. The enzymes of this group constitute an electron donor for other important oxidoreductive enzymes, e.g. ribonucleotide reductase and thioredoxin peroxidase. The thioredoxins alone reveal properties of apoptosis inhibitors, growth factors, and hydroperoxidase reducers. In addition, TRRs may reduce oxidised glutathione, dehydroascorbic acid, vitamin K, lipid peroxides, and hydrogen peroxide [48].

SPP1, besides its role of selenium storage site and transporter along the system, acts as a heavy metal chelator. It creates non-toxic complexes with them and may also exert anti-tumour activity $[49,50]$. Selenoprotein $W$ is responsible for metabolism of the muscular system, and $\mathrm{N}$ for muscle tissue development $[3,51]$. It has been shown that certain mutations in the gene for selenoprotein $\mathrm{N}$ can cause multiminicore myopathy [51]. Other selenoproteins (S,M) were alsoidentified [47,52,53], but their role is not yet well understood.

It mentioned earlier, selenium can control the functions of the immune system $[1,2]$. It has been demonstrated that the above-mentioned element can stimulate the synthesis of antibodies, especially of IgG and IgM, and activate lymphocytes $\mathrm{T}$ and macrophages [38]. It has also been proven that selenium-containing compounds may suppress the transformation of HIV infection to fully symptomatic AIDS [54]. Selenium also exerts antiviral and antibacterial effects and inhibits the progression of various forms of viral hepatitis. It may also prevent infections with RNAs of certain viruses, among others, of the Ebola virus [1, 2, 55, 56].

The postulated anti-tumour properties of selenium are largely based on its already mentioned antioxidative properties. The advantageous effects of selenium on the activation of NK lymphocytes should be mentioned as well [50]. Thus far, the positive properties of selenium have been described in the context of colonic, prostatic, and pulmonary carcinoma [52]. There are also reports on the role of selenium in the conductivity of impulses in the central nervous system (CNS) [1,57]. Moreover, the above-mentioned microelement may prevent diabetes mellitus, cardiovascular diseases, and infertility [26, 32].

\section{Selenium and the thyroid gland}

Thyroid diseases are considered to be among the most frequent medical conditions in general, and, decisively, they are the most frequent problems of endocrine character with which patients visit their GPs [58-60], while L-thyroxin is in the top ten of the most frequently prescribed and taken medicinal products [58,61]. 
It is now assumed that proper functioning of the TG, besides iodine, also requires a number of elements, including selenium, iron, zinc, copper, and calcium [44, 62-67]. In many cases, only an adequate supply of one of these microelements (e.g. iodine) can reveal symptoms resulting from deficits of other microelements (e.g. iron or selenium) $[62,63,66]$. A proper sequence of particular supplementations is also worth emphasising for the significant correlations among the supplemented microelements. For example, it has been demonstrated that excessive supplementation of selenium may enhance the effects of iodine deficit in endemic regions, while proper supplementation of selenium in studied animals may alleviated the consequences of iodine excess, preventing destructive-inflammatory lesions in the TG [44, 68-72]. The TG, similarly to the testes and the brain, and unlike other organs in the human body, is characterised by high selenium content, despite its deficit in the system [44]. Studies carried out in patients with mutations of selenocysteine insertion sequence (SECIS) binding protein 2, may provide good proof of the significant role of selenium on the thyroid metabolism. This protein plays a significant role in the synthesis of selenoproteins. It has been observed that various mutations of the gene for the above-mentioned protein are, among others, responsible for the characteristic hormonal configuration: increased concentrations of TSH and FT4 and a decreased concentration of FT3 plus sensorineural hearing loss. Moreover, other, more characteristic features may occur, such as impaired development of the osseous system, myopathy, disturbances in CNS development, regarding the motor abilities, hypersensitivity to UV, and enhanced insulin sensitivity [73-76].

As already mentioned, all the DIOs, as well as other proteins, including GPs and TRRs, contain selenium atoms. A high activity of these enzymes has been demonstrated in the thyroid tissue; however, in order to maintain iodine metabolism, catalysed by deiodinases, and at an appropriate level, low activity of these enzymes will be enough, much lower than of other selenoproteins in the pathways of the metabolic turnover of proteins, fats, and amino acids [34, 77, 78]. Therefore, neither the concentration of selenium nor the concentrations of selenium-containing proteins directly influence the selenium content in the thyroid and the activity of selenoproteins contained in the TG [69, 79]. There is no data in the available literature concerning the measurable parameters that would unequivocally and reliably reflect thyroid supplementation with selenium.

A number of significant clinical data on the role of selenium supplementation in TG homeostasis were provided by studies carried out in Central Africa during the 1980s. Symptoms of cretinism with myxoedema were observed in the population living within that area, including mental retardation, growth suppression, and impaired puberty. The studies further confirmed that all those conditions had been associated with iodine and selenium deficits on one hand, and with the consumption of large quantities of foods containing goitrogens on the other [44, 80]. Negative additive effects, resulting from deficits of either microelement, have also been confirmed by the results of studies on animals $[80,81]$. Most probably, it is the transforming growth factor $\beta$ (TGF $\beta$ ) which is responsible for thyroid tissue damage and fibrosis resulting from selenium deficits. TGF $\beta$ mediates the stimulation of destruction, caused by oxidative stress and initiated by high TSH concentrations [71]. In turn, appropriate selenium supplementation protects from the described processes, even when iodine supplementation is high, following its long-term deficit [68, 71, 72, 80]. According to the results of studies carried out in Zair, selenium supplementation without previous compensation of iodine deficit may deteriorate the patient's thyroid functioning; therefore, previous iodine assays and supplementation, if necessary, are required [80]. An increased activity of deiodinases and an increased metabolism of $\mathrm{TH}$, with their enhanced deiodination and iodine loss with urine, are assumed to be the mechanism of this phenomenon [44]. The above described clinical situation concerned a severe deficit of both microelements.

There are many hypotheses concerning the protective role of selenium in thyroid diseases. At present, it is assumed that proper selenium supplementation may [41]:

1. decrease the expression of HLA-DR antigens on thyrocyte surface,

2. cause a decrease in the concentrations of antithyroid antigen antibodies,

3. control the lymphocyte B-dependent immunological response,

4. inhibit the production of proinflammatory cytokines,

5. reduce the synthesis of leukotrienes and prostaglandins,

6. protect the thyroid against oxidative stress,

7. optimise the synthesis and transport of $\mathrm{TH}$ via induction of selenoprotein synthesis (among others, p15 and S) [82-84].

In recent years, several selenium-containing analogues of thyrostatics have been produced, as well as of compounds that imitate the action mode of selenoproteins [85-88]. The anti-thyroid drugs that are currently available on the market may cause a number of unpleasant adverse effects [89]; therefore, a possibility of the synergistic effect of action on the suppression of not only the biosynthesis but also of the activation of $\mathrm{TH}-$ or their activation alone - may lead to a new, valuable therapeutic option for patients with hyperthyroidism 
of different aetiologies and will be better tolerated than already available anti-thyroid medications [90].

One of the first interventional studies in which the supplementation of various vitamins and microelements was applied, demonstrated that too small supplementation of selenium influenced the growth of the TG only in women [91]. Analogous results were obtained when a Danish population was examined, also finding out a reverse correlation between selenium concentrations and the number of focal changes in the TG [92]. Changes in serum selenium levels were also observed in other benign and malignant diseases of the TG [93]. As is common knowledge, the incidence of thyroid diseases is higher in women than in men [94]; however, no causes of this phenomenon have yet been adequately understood. An influence of female sex hormones is postulated, as well as the protective activity of factors that depend on the presence of chromosome $Y$ or on the different mechanisms by which the immune systems function in both sexes. It is also worth emphasising that the advantageous effects of selenium in cases of thyroid diseases have been demonstrated in women, while in men it has been shown in other organs [83, 95-98].

Data that confirm the hypothesis of the beneficial selenium supplementation effects in the case of thyroid cancer are rather scarce and apply mainly to its papillary form [99-101]. In many studies on animal models, as well as in epidemiological and interventional surveys, beneficial effects were confirmed of normal or even increased serum selenium concentrations on the initiation, progression, and even metastases of various cancer types but not of thyroid cancer [50, 102]. The relationship between selenium supplementation and the incidence of thyroid cancer has been verified in many clinical studies (Table I); however, it has not been unequivocally confirmed, especially in the Polish population [103-111]. The access to mainly retrospective data, the relatively small groups of patients, and the short observation periods, as well as only single assays of selenium concentration levels, were all significant limitations in the performed studies. One should also consider the fact that low selenium concentrations may be not a cause but a result of some concomitant systemic diseases, also neoplastic, even in the effects of sustained chronic inflammation, which may impair the production of SPP1 in the liver, which, as is known, reflects the body's supply with this microelement [112-115].

\section{Selenium in autoimmune diseases of the thyroid gland}

It is known that selenium affects the process of differentiation of Tlymphocytes in such a way that its increasing supplementation may induce increased production of regulatory $\mathrm{T}$ lymphocytes and a decrease of the synthesis of anti-thyroid antigen antibodies and of lymphocyte infiltrations [116], while its deficit may enhance the activity of Th2 lymphocytes [117]. In addition, it has been demonstrated on an animal model of chronic autoimmune thyroiditis (CAT) that selenium supplementation suppresses the Th1-dependent immune responses, thus inhibiting the inflammatory response and the occurrence of destructive lesions in the TG [118]. Moreover, in blood from healthy males, supplemented with a selenium-containing agent, a lower number of NK lymphocytes was observed [119]. The presented results suggest beneficial effects of selenium on the autoimmune diseases of the TG $[83,120]$. In women at risk of postpartum thyroiditis, proper supplementation of the microelement may provide a prophylactic effect against the disease, although the data from clinical studies still require additional confirmation [121, 122].

In addition, lower selenium concentrations were found in serum from patients with Graves' disease and with hypothyroidism in the course of CAT. However, the results of studies on the correlation between the concentrations of anti-TPO, anti-TG, and anti-TSHR antibodies and selenium supplementation rates are much less conclusive [123]. In many interventional studies, no relationship was found between the time of selenium intake and selenium dose on one hand, and changes in the concentrations of TSH and TH on the other; however, most of the studies were not carried out in cases of severe selenium deficit $[44,98,124,125]$. Therefore, the results of those studies may have also been a consequence of good mechanisms of supplementation with selenium of the TG and of the anterior pituitary, despite maintained systemic selenium deficit.

A number of prospective studies have also been run to evaluate the severity of symptoms resulting from identified autoimmune thyroid disease, as well as to assess the quality of patient life and TH production rates and concentration levels. The results of meta-analyses of the studies are often divergent and non-unequivocal. In one of the meta-analyses [123] its authors evaluated the results of four clinical studies assessing the effect of supplementation with sodium selenate (IV) and with selenomethionine in a daily dose of $200 \mu \mathrm{g}$ on various end-points in patients with diagnosed CAT. In each of the three studies, where selenomethionine had been used, a significant reduction was found in the concentration of anti-TPO antibodies. That effect was not significant in the population, which had been supplemented with selenate; however, improved quality of patient life was reported by patients from that population [123]. Despite all the encouraging beneficial and supplementation results, the authors of the above described statistical analysis recommend a precaution- 
Table I. Short characteristics of the most important clinical trials, concerning the relationship between selenium and thyroid cancer

\begin{tabular}{|c|c|c|c|c|c|}
\hline Study & Studied group & $\begin{array}{l}\text { Study type } \\
\text { and duration }\end{array}$ & $\begin{array}{l}\text { Description of } \\
\text { intervention-group }\end{array}$ & $\begin{array}{l}\text { The most important, } \\
\text { evaluated } \\
\text { parameters }\end{array}$ & The most important results \\
\hline $\begin{array}{l}\text { Glattre et al. } \\
\text { Int J Epidemiol } \\
\text { (1989) [103] }\end{array}$ & $\begin{array}{l}\text { Population of } 172 \\
\text { patients } \\
\text { (124 women and } \\
48 \text { men) }\end{array}$ & $\begin{array}{l}\text { Cross-sectional } \\
\text { study }\end{array}$ & $\begin{array}{l}\text { Control group ( } n=129 \text { ) } \\
\text { Study group with thyroid } \\
\text { carcinoma }(n=43)\end{array}$ & $\begin{array}{l}\text { Differences in } \\
\text { serum selenium } \\
\text { concentrations and } \\
\text { their association with } \\
\text { the risk of thyroid } \\
\text { carcinoma }\end{array}$ & $\begin{array}{l}\text { Lower selenium concentrations in } \\
\text { patients with thyroid carcinoma } \\
\text { Relative risks (RR) for thyroid carcinoma } \\
\text { depending on selenium concentrations: } \\
\mathrm{RR}=1 \text { for } \geq 1.65 \mu \mathrm{mol} / \mathrm{L} \\
\mathrm{RR}=6.1 \text { for } 1.26-1.64 \mu \mathrm{mol} / \mathrm{L} \\
\mathrm{RR}=7.7 \text { for } \geq 1.25 \mu \mathrm{mol} / \mathrm{L}\end{array}$ \\
\hline
\end{tabular}

\begin{tabular}{|c|c|c|c|c|c|}
\hline $\begin{array}{l}\text { Kucharzewski } \\
\text { et al. Biol Trace } \\
\text { Elem Res } \\
\text { (2002) [104] }\end{array}$ & $\begin{array}{l}\text { Population of } \\
87 \text { subjects ( } 85 \\
\text { women and } 2 \\
\text { men) }\end{array}$ & $\begin{array}{l}\text { Cross-sectional } \\
\text { study }\end{array}$ & $\begin{array}{l}\text { Patients with benign thyroid } \\
\text { diseases ( } 41 \text { women with } \\
\text { nodular goitre, } 18 \text { with } \\
\text { Graves' disease, } 7 \text { with } \\
\text { CAT) } \\
21 \text { patients with thyroid } \\
\text { carcinoma ( } 19 \text { women and } \\
2 \text { men) }\end{array}$ & $\begin{array}{l}\text { Differences in the } \\
\text { concentrations of } \\
\text { selenium in serum } \\
\text { and in thyroid tissue }\end{array}$ & $\begin{array}{l}\text { Insignificant differences among } \\
\text { the groups in serum selenium } \\
\text { concentrations } \\
\text { Significantly lower selenium } \\
\text { concentration in thyroid tissue - in } \\
\text { the group of patients with thyroid } \\
\text { carcinoma }\end{array}$ \\
\hline $\begin{array}{l}\text { Moncayo et al. } \\
\text { BMC Endocr } \\
\text { Disord (2008) } \\
{[105]}\end{array}$ & $\begin{array}{l}1401 \text { patients } \\
\text { ( } 1186 \text { adults and } \\
215 \text { children) } \\
\text { with benign } \\
\text { thyroid diseases } \\
\text { and thyroid } \\
\text { carcinoma }\end{array}$ & $\begin{array}{l}\text { Cross-sectional } \\
\text { study }\end{array}$ & $\begin{array}{l}\text { Groups concerning selenium } \\
\text { analysis: } \\
\text { Control ( } \mathrm{n}=687 \text { ) } \\
\text { Benign thyroid diseases } \\
\text { ( } \mathrm{n}=550 ; 465 \text { adults, } \\
85 \text { children) } \\
\text { Thyroid carcinoma } \\
\text { ( } \mathrm{n}=164 \text { ); } 42 \text { with follicular, } \\
73 \text { with papillary and } \\
3 \text { with anaplastic thyroid } \\
\text { carcinoma }\end{array}$ & $\begin{array}{l}\text { Differences in } \\
\text { serum selenium } \\
\text { concentrations and } \\
\text { an evaluation of the } \\
\text { correlation of this } \\
\text { concentration with } \\
\text { other measurable } \\
\text { parameters }\end{array}$ & $\begin{array}{l}\text { Selenium concentration was } \\
\text { significantly lower in: } \\
\text { 1. The population of patients with } \\
\text { thyroid diseases vs. the control } \\
\text { 2. The subgroups with subacute and } \\
\text { silent thyroiditis } \\
\text { 3. In the group of patients with follicular } \\
\text { and papillary carcinoma } \\
\text { No significant correlations between } \\
\text { selenium concentration and patient's } \\
\text { age, gender, BMl, scintigraphic and } \\
\text { sonographic pictures of the thyroid } \\
\text { gland, hormone concentrations and } \\
\text { anti-thyroid antigen antibodies }\end{array}$ \\
\hline $\begin{array}{l}\text { Przybylik- } \\
\text { Mazurek et al. } \\
\text { Biol Trace Elem } \\
\text { Res (2011) [106] }\end{array}$ & $\begin{array}{l}\text { Women with } \\
\text { CAT, follicular } \\
\text { and papillary } \\
\text { thyroid } \\
\text { carcinoma }\end{array}$ & $\begin{array}{l}\text { Cross-sectional } \\
\text { study }\end{array}$ & $\begin{array}{l}\text { Control }(n=20) \\
\text { Women with CAT ( } n=17) \\
\text { Patients with papillary } \\
\text { carcinoma }(n=25) \\
\text { Patients with follicular } \\
\text { carcinoma }(n=13)\end{array}$ & $\begin{array}{l}\text { Differences in the } \\
\text { concentrations of } \\
\text { microlements in } \\
\text { serum, including, } \\
\text { among others, } \\
\text { selenium and } \\
\text { glutathione } \\
\text { peroxidase (PG) } 3\end{array}$ & $\begin{array}{l}\text { No significant differences among } \\
\text { the groups in selenium and PG3 } \\
\text { concentrations }\end{array}$ \\
\hline $\begin{array}{l}\text { Jonklaas et al. } \\
\text { Thyroid (2013) } \\
{[107]}\end{array}$ & $\begin{array}{l}65 \text { patients } \\
\text { qualified to the } \\
\text { procedure of } \\
\text { thyroidectomy } \\
\text { (46 women and } \\
19 \text { men) }\end{array}$ & $\begin{array}{l}\text { Cross-sectional } \\
\text { study }\end{array}$ & $\begin{array}{l}\text { Patients qualified to } \\
\text { procedure for goitre } \\
\text { occurrence ( } n=17 \text { ) } \\
\text { Patients qualified to procedure } \\
\text { for thyroid cancer ( } n=48 \text {; in } \\
\text { histopathological diagnosis: } \\
35 \text { cases of papillary } \\
\text { carcinoma and } 9 \text { cases of its } \\
\text { follicular variant and } 4 \text { cases } \\
\text { of follicular carcinoma) }\end{array}$ & $\begin{array}{l}\text { Comparative } \\
\text { evaluation of } \\
\text { preoperative selenium } \\
\text { and } 25(\mathrm{OH}) \text { vit. D3 } \\
\text { concentrations in } \\
\text { serum and their } \\
\text { correlation with the } \\
\text { stage of the diseases } \\
\text { severity }\end{array}$ & $\begin{array}{l}\text { 1. Insignificant concentration } \\
\text { differences among the groups } \\
\text { 2. Reverse, significant correlation } \\
\text { between selenium concentration and } \\
\text { carcinoma stage }\end{array}$ \\
\hline $\begin{array}{l}\text { 0`Grady et al. } \\
\text { PLoS One (2014) } \\
{[108]}\end{array}$ & $\begin{array}{l}566398 \text { patients } \\
\text { qualified to } \\
\text { NIH-AARP } \\
\text { study (National } \\
\text { Institute of } \\
\text { Health American } \\
\text { Association of } \\
\text { Retired Persons }\end{array}$ & $\begin{array}{l}\text { The } \\
\text { prospective } \\
\text { study (initiated } \\
\text { in 1995) }\end{array}$ & $\begin{array}{l}\text { In the studied population, } \\
592 \text { cases of carcinoma } \\
\text { were identified ( } 257 \text { men } \\
\text { and } 335 \text { women): } \\
406 \text { diagnoses of papillary } \\
\text { carcinoma ( } 164 \text { cases in } \\
\text { men and } 242 \text { in women), } \\
113 \text { diagnoses of follicular } \\
\text { carcinoma ( } 57 \text { in men and } \\
56 \text { in women) }\end{array}$ & $\begin{array}{l}\text { Evaluation of the } \\
\text { correlation between } \\
\text { the consumption } \\
\text { of selenium, as } \\
\text { well as of other } \\
\text { microelements and } \\
\text { vitamins on one hand } \\
\text { and the incidence rate } \\
\text { of thyroid carcinoma } \\
\text { on the other }\end{array}$ & $\begin{array}{l}\text { No significant correlation was found } \\
\text { between the quintiles of lower selenium } \\
\text { consumption and the increased } \\
\text { incidence of thyroid cancer }\end{array}$ \\
\hline
\end{tabular}


Table I (cont.). Short characteristics of the most important clinical trials, concerning the relationship between selenium and thyroid cancer

\begin{tabular}{|c|c|c|c|c|c|}
\hline $\begin{array}{l}\text { Shen et al. } \\
\text { Biol Trace Elem } \\
\text { Res } \\
(2015)[109]\end{array}$ & $\begin{array}{l}\text { Metaanalysis } \\
\text { of data from } 8 \\
\text { clinical studies } \\
\text { ( } 4 \text { concerning } \\
\text { selenium). The } \\
\text { total number of } \\
\text { patients: } 1291\end{array}$ & Metaanalysis & $\begin{array}{l}\text { Metanalysis of data from } \\
\text { studies, carried out in the } \\
\text { following populations: } \\
\text { Norwegian, Austrian and } \\
\text { Polish }\end{array}$ & $\begin{array}{l}\text { Differences in the } \\
\text { concentrations of } \\
\text { selenium, copper and } \\
\text { magnesium in serum }\end{array}$ & $\begin{array}{l}\text { 1. Significantly lower selenium and } \\
\text { magnesium concentrations and higher } \\
\text { copper concentrations in patients with } \\
\text { thyroid carcinoma } \\
\text { 2. An analysis in the subgroups } \\
\text { confirmed the presence of lower } \\
\text { selenium concentrations in the } \\
\text { Norwegian and Austrian populations } \\
\text { but not in the Polish one }\end{array}$ \\
\hline $\begin{array}{l}\text { Baltaci et al. } \\
\text { Biol Trace Elem } \\
\text { Res (2016) [110] }\end{array}$ & $\begin{array}{l}50 \text { patients of } \\
\text { both sexes ( } 30 \\
\text { subjects with } \\
\text { histopathological } \\
\text { diagnosis of } \\
\text { papillary thyroid } \\
\text { cancer) }\end{array}$ & $\begin{array}{l}\text { Cross-sectional } \\
\text { study }\end{array}$ & $\begin{array}{l}\text { Women with post-operative } \\
\text { diagnosis of thyroid cancer } \\
\text { ( } \mathrm{n}=15 \text { ) } \\
\text { Men with post-operative } \\
\text { diagnosis of thyroid cancer } \\
(\mathrm{n}=15) \\
\text { Women with benign } \\
\text { changes in histopathological } \\
\text { evaluation } \\
\text { Men with benign changes in } \\
\text { histopathological evaluation }\end{array}$ & $\begin{array}{l}\text { Comparison of } \\
\text { selenium and zinc } \\
\text { concentrations } \\
\text { in serum before, } \\
\text { just after and } 15 \\
\text { days after surgical } \\
\text { procedure and in the } \\
\text { thyroid tissue after } \\
\text { operation }\end{array}$ & $\begin{array}{l}\text { 1. Pre- and postoperative zinc and } \\
\text { selenium concentrations in Group } 1 \\
\text { and } 2 \text { were significantly lower in serum } \\
\text { and higher in the thyroid tissue vs. the } \\
\text { corresponding values in the control } \\
\text { groups } \\
\text { 2. After } 15 \text { days from the surgical } \\
\text { procedure, no significant differences } \\
\text { were observed among the groups }\end{array}$ \\
\hline $\begin{array}{l}\text { Chung et al. } \\
\text { Biol Trace Elem } \\
\text { Res (2016) [111] }\end{array}$ & $\begin{array}{l}\text { Ninety-two (92) } \\
\text { Korean women, } \\
\text { qualified to the } \\
\text { procedure of } \\
\text { thyroidectomy }\end{array}$ & $\begin{array}{l}\text { Cross-sectional } \\
\text { study }\end{array}$ & $\begin{array}{l}\text { Ninety-two (92) Korean } \\
\text { women, qualified to the } \\
\text { procedure of thyroidectomy } \\
\text { and with post-operative, } \\
\text { histopathological } \\
\text { identification of papillary } \\
\text { thyroid cancer }\end{array}$ & $\begin{array}{l}\text { Evaluation of the } \\
\text { concentrations/ } \\
\text { contents of cadmium, } \\
\text { selenium and zinc } \\
\text { in post-operative } \\
\text { materials and of their } \\
\text { correlations with } \\
\text { the stage of thyroid } \\
\text { cancer progression }\end{array}$ & $\begin{array}{l}\text { Acc. to TNM, cadmium, selenium and } \\
\text { zinc concentrations were significantly } \\
\text { higher in stages III and IV }\end{array}$ \\
\hline
\end{tabular}

CAT — chronic autoimmune thyroiditis

ary approach to the issue for the high heterogeneity and the relatively small numbers of the studied populations, different observation time periods (7.5 months on average), and a high risk of bias [123]. While studying the effects of selenium on patients with Hashimoto's disease, the authors of another meta-analysis [120] also found a significant decrease in the concentration of antiTPO antibodies and some improvement in the quality of life of those patients already after three months of supplementation. Moreover, those authors observed a correlation between the strength of the response to supplementation and the initial concentrations of antiTPO antibodies. Nine studies and a total of 787 patients were taken into account in another meta-analysis. All the patients received $200 \mu \mathrm{g}$ of selenate or selenomethionine and, possibly, additional doses of L-thyroxin (in four clinical studies) and methimazole (in one clinical study). In a clear majority the patients were diagnosed with CAT, while in one study the efficacy of the therapy was evaluated in patients with diffuse toxic goitre. A six-month supplementation brought about a significant drop in the concentrations of anti-TPO antibodies. In turn, the results obtained after 12 months of therapy demonstrated a significant drop in the levels of antiTG and also anti-TPO antibodies. In addition, based on the data from two studies, the beneficial effect of selenium supplementation was confirmed regarding the mood of the patients [126]. Brief characteristics of the most important prospective clinical studies [98, 122, 127-144] concerning the efficacy of supplementation with selenium in benign thyroid diseases, in particular autoimmune diseases, are presented in Table II.

\section{The role of selenium in thyroid gland pathophysiology}

Marcocci et al. [145] studied the efficacy of supplementation with selenium in a population of 159 patients with mild Graves' ophthalmopathy. The population was divided into three groups: the first group (control) received placebo, the second $-600 \mathrm{mg}$ of pentoxifylline twice daily, and the third $-100 \mu \mathrm{g}$ of sodium selenate (IV) twice daily. After six months of therapy with sodium selenate, the researchers observed a significant improvement in the quality of life of their patients, less intensity in the ophthalmological changes, and suppression of orbitopathy progression into its more severe forms. The intensity of ophthalmological changes, evaluated by the Clinical Activity Score (CAS), was reduced in all the groups, but it was significantly lower in the group receiving selenium. The results, obtained 
Table II. Main characteristics of major clinical studies concerning the relationship between selenium and benign thyroid diseases

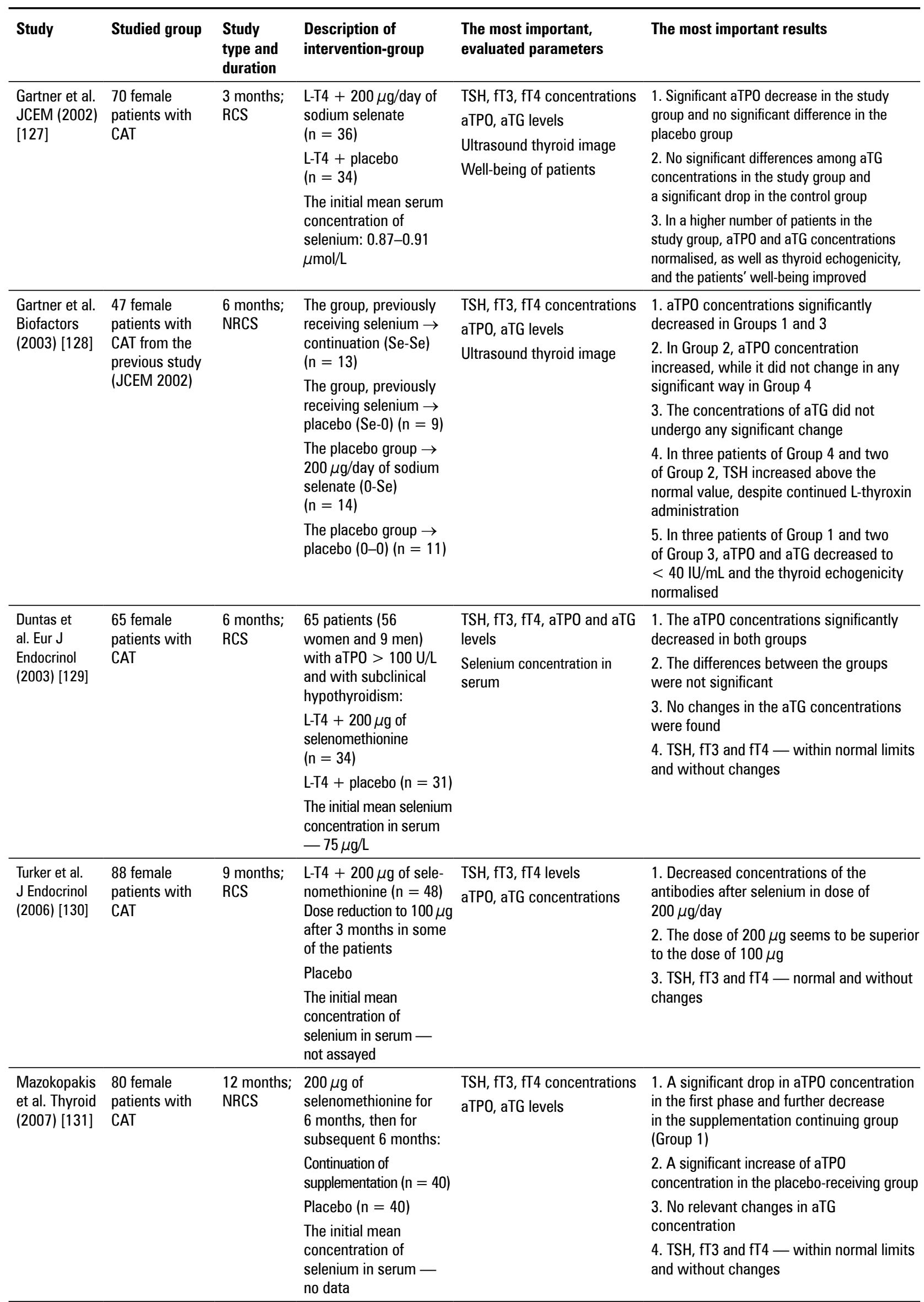


Table II (cont.). Main characteristics of major clinical studies concerning the relationship between selenium and benign thyroid diseases

\begin{tabular}{|c|c|c|c|c|c|}
\hline $\begin{array}{l}\text { Negro et al. } \\
\text { JCEM (2007) } \\
\text { [122] }\end{array}$ & $\begin{array}{l}\text { Pregnant } \\
\text { euthyroid } \\
\text { women: } 169 \\
\text { with high } \\
\text { concentrations } \\
\text { of aTPO and } \\
85 \text { with low } \\
\text { concentrations } \\
\text { of aTPO }\end{array}$ & $\begin{array}{l}\text { From } \\
\text { the 12th } \\
\text { week of } \\
\text { pregnancy } \\
\text { through the } \\
\text { 12th month } \\
\text { after birth } \\
\text { RCS }\end{array}$ & $\begin{array}{l}200 \mu \mathrm{g} \text { of } \\
\text { selenomethionine } \\
\text { (n=85) } \\
\text { Placebo }(\mathrm{n}=84) \\
\text { The aTPO control group } \\
(-)(\mathrm{n}=85) \\
\text { The initial mean } \\
\text { concentration of } \\
\text { selenium in serum } \\
-78.8 \mu \mathrm{g} / \mathrm{L}\end{array}$ & $\begin{array}{l}\text { TSH, fT4, aTPO levels } \\
\text { Selenium concentration in } \\
\text { serum } \\
\text { Ultrasound thyroid image }\end{array}$ & $\begin{array}{l}\text { 1. Lower incidence of the postpartum } \\
\text { thyroiditis and of permanent } \\
\text { hypothyroidism in the selenium-receiving } \\
\text { group } \\
\text { 2. Without changes in the ultrasound } \\
\text { image in selenium group. A significant } \\
\text { deterioration of ultrasound image in the } \\
\text { control group at the end of the observation } \\
\text { period in comparison with the early } \\
\text { pregnancy }\end{array}$ \\
\hline $\begin{array}{l}\text { Karanikas et } \\
\text { al. Thyroid } \\
\text { (2008) [132] }\end{array}$ & $\begin{array}{l}36 \text { female } \\
\text { patients with } \\
\text { CAT }\end{array}$ & $\begin{array}{l}3 \text { months; } \\
\text { RCS }\end{array}$ & $\begin{array}{l}\mathrm{L}-\mathrm{T} 4+200 \mu \mathrm{g} \text { of sodium } \\
\text { selenate }(\mathrm{n}=18) \\
\mathrm{L}-\mathrm{T} 4+\text { placebo } \\
(\mathrm{n}=18) \\
\text { The initial mean } \\
\text { concentration of } \\
\text { selenium in serum - } \\
75 \mu \mathrm{g} / \mathrm{L}\end{array}$ & $\begin{array}{l}\text { Thyroid hormones and aTPO } \\
\text { Well-being of patients } \\
\text { Lymphocytic cytokines levels } \\
\text { Selenium concentration in } \\
\text { serum }\end{array}$ & $\begin{array}{l}\text { 1. No significant differences among the } \\
\text { groups, regarding the results of laboratory } \\
\text { tests } \\
\text { 2. Improved well-being more often reported } \\
\text { by patients from the selenium taking group. } \\
\text { TSH, fT3 and fT4 - normal and without } \\
\text { significant changes }\end{array}$ \\
\hline $\begin{array}{l}\text { Combs et al. } \\
\text { Am J Clin } \\
\text { Nutr (2009) } \\
\text { [98] }\end{array}$ & $\begin{array}{l}28 \text { healthy } \\
\text { subjects } \\
(13 \text { men) }\end{array}$ & $\begin{array}{l}28 \text { months; } \\
\text { NRCS }\end{array}$ & $\begin{array}{l}\text { All the patients } \\
\text { received } 200 \mu \mathrm{g} \text { of } \\
\text { selenomethionine/day } \\
\text { for } 28 \text { months } \\
\text { The initial mean } \\
\text { concentration of } \\
\text { selenium in serum - } \\
1.64 \mu \mathrm{mol} / \mathrm{L} \text { for women } \\
\text { and } 1.78 \mu \mathrm{mol} / \mathrm{L} \text { for } \\
\text { men }\end{array}$ & $\begin{array}{l}\text { TSH, T3,T4 } \\
\text { Serum selenium concentration }\end{array}$ & $\begin{array}{l}\text { A } 5 \% \text {, significant increase of T3 } \\
\text { concentration / year, without } \\
\text { accompanying changes of TSH or T4 }\end{array}$ \\
\hline $\begin{array}{l}\text { Bonfig et al. } \\
\text { Scientific } \\
\text { World Journal } \\
\text { (2010) [133] }\end{array}$ & $\begin{array}{l}49 \text { children at } \\
\text { the mean age } \\
\text { of } 12.2 \pm 2.2 \\
\text { years ( } 33 \text { girls) } \\
\text { with newly } \\
\text { diagnosed } \\
\text { CAT and } \\
\text { hypothyroidism }\end{array}$ & $\begin{array}{l}12 \text { months; } \\
\text { RCS }\end{array}$ & $\begin{array}{l}\mathrm{L}-\mathrm{T} 4 \text { (14 women and } \\
4 \text { men) } \\
\mathrm{L}-\mathrm{T} 4+100 \mu \mathrm{g} / \text { day of } \\
\text { sodium selenate } \\
\text { ( } 9 \text { women and } 4 \text { men) } \\
\mathrm{L}-\mathrm{T} 4+200 \mu \mathrm{g} / \text { day of } \\
\text { sodium selenate (10 } \\
\text { women and } 8 \text { men) } \\
\text { The initial mean } \\
\text { concentration of } \\
\text { selenium in serum - } \\
\text { no data }\end{array}$ & $\begin{array}{l}\text { TSH, fT3, fT4 concentrations } \\
\text { aTP0, aTG levels }\end{array}$ & $\begin{array}{l}\text { 1. The aTPO concentrations were } \\
\text { comparable in all the groups, both at study } \\
\text { onset and after } 12 \text { months of therapy } \\
\text { 2. The concentrations of aTG significantly } \\
\text { decreased in Group } 1 \text { and } 3 \text { after } 12 \\
\text { months }\end{array}$ \\
\hline $\begin{array}{l}\text { Nacamulli } \\
\text { et al. Clin } \\
\text { Endocrinol } \\
\text { (0xf) (2010) } \\
\text { [134] }\end{array}$ & $\begin{array}{l}76 \text { patients } \\
\text { (including } \\
65 \text { women) } \\
\text { with CAT, in } \\
\text { euthyreosis or } \\
\text { with subclinical } \\
\text { hypothyroidism }\end{array}$ & $\begin{array}{l}12 \text { months; } \\
\text { RCS }\end{array}$ & $\begin{array}{l}\text { Placebo ( } 25 \text { women and } \\
5 \text { men) } \\
80 \mu \mathrm{g} \text { of sodium } \\
\text { selenate for } 6 \text { months } \\
\text { ( } 40 \text { women and } 6 \text { men) } \\
\text { The initial mean } \\
\text { concentration of selenium } \\
\text { in serum — no data }\end{array}$ & $\begin{array}{l}\text { TSH, fT4 concentrations } \\
\text { aTPO, aTG levels } \\
\text { Ultrasound thyroid image }\end{array}$ & $\begin{array}{l}\text { 1. No significant changes in TSH or fT4 } \\
\text { levels, either in the groups or among them } \\
\text { 2. A significant drop in aTPO and aTG levels } \\
\text { in Group } 2 \text { after } 12 \text { months } \\
\text { 3. A significant decrease of echogenicity } \\
\text { in both groups after } 6 \text { months and its } \\
\text { further drop after } 12 \text { months in the control } \\
\text { group }\end{array}$ \\
\hline $\begin{array}{l}\text { Krysiak i } \\
\text { Okopien } \\
\text { JCEM (2011) } \\
\text { [135] }\end{array}$ & $\begin{array}{l}170 \text { euthyroid } \\
\text { women with } \\
\text { CAT and } 41 \\
\text { health subjects }\end{array}$ & $\begin{array}{l}6 \text { months; } \\
\text { RCS }\end{array}$ & $\begin{array}{l}\text { Female patients with } \\
\text { newly diagnosed and } \\
\text { untreated CAT: } \\
\text { L-T4 (42) } \\
200 \mu \mathrm{g} \text { of } \\
\text { selenomethionine (43) } \\
\mathrm{L}-\mathrm{T} 4+200 \mu \mathrm{g} \text { of } \\
\text { selenomethionine (43) } \\
\text { Placebo (42) } \\
\text { The initial mean } \\
\text { concentration of } \\
\text { selenium in serum - } \\
\text { not assayed ( } 57.5 \mu \mathrm{g} / \mathrm{L} \\
\text { at that region of Poland) }\end{array}$ & $\begin{array}{l}\text { ATPO concentrations } \\
\text { Levels of lymphocytic and } \\
\text { monocytic cytokines } \\
\text { Concentrations of acute phase } \\
\text { parameters }\end{array}$ & $\begin{array}{l}\text { The highest decrease in the concentrations } \\
\text { of aTPO, hsCRP and secreted cytokines } \\
\text { was noted In the group on combined } \\
\text { therapy }\end{array}$ \\
\hline
\end{tabular}


Table II (cont.). Main characteristics of major clinical studies concerning the relationship between selenium and benign thyroid diseases

\begin{tabular}{|c|c|c|c|c|c|}
\hline $\begin{array}{l}\text { Onal et al. } \\
\text { J Pediatr } \\
\text { Endocrinol } \\
\text { Metab (2012) } \\
\text { [136] }\end{array}$ & $\begin{array}{l}\text { Twenty-three } \\
\text { (23) euthyroid } \\
\text { children at the } \\
\text { age of } 12.3 \\
\pm 2.4 \text { years } \\
\text { with freshly } \\
\text { diagnosed CAT } \\
\text { (16 girls and } \\
7 \text { boys) }\end{array}$ & $\begin{array}{l}3 \text { months; } \\
\text { NRCS }\end{array}$ & $\begin{array}{l}\text { All the study } \\
\text { participants received } \\
\text { a daily dose of } 50 \mu \mathrm{g} \text { of } \\
\text { selenomethionine for } \\
3 \text { months } \\
\text { The initial mean } \\
\text { concentration of } \\
\text { selenium in serum - } \\
\text { no access to data }\end{array}$ & $\begin{array}{l}\text { TSH, fT3, fT4, aTP0, aTG } \\
\text { concentrations } \\
\text { Ultrasound thyroid image } \\
\text { Serum selenium } \\
\text { concentration }\end{array}$ & $\begin{array}{l}\text { 1. The concentrations of aTPO and of aTG, } \\
\text { as well as thyroid echogenicity did not } \\
\text { change } \\
\text { 2. In } 35 \% \text { of the patients, the thyroid size } \\
\text { decreased by } \geq 30 \%\end{array}$ \\
\hline $\begin{array}{l}\text { Anastasilakis } \\
\text { et al. Int J Clin } \\
\text { Pract (2012) } \\
\text { [137] }\end{array}$ & $\begin{array}{l}86 \text { patients with } \\
\text { CAT (including } \\
33 \text { men) }\end{array}$ & $\begin{array}{l}6 \text { month of } \\
\text { quasi-RCS }\end{array}$ & $\begin{array}{l}200 \mu \mathrm{g} \text { of } \\
\text { selenomethionine for } \\
3 \text { months }(\mathrm{n}=15) \\
200 \mu \mathrm{g} \text { of } \\
\text { selenomethionine for } \\
6 \text { months }(\mathrm{n}=46) \\
\text { Placebo ( } \mathrm{n}=25) \\
\text { The initial mean } \\
\text { concentration of } \\
\text { selenium in serum - } \\
83 \mu \mathrm{g} / \mathrm{L}\end{array}$ & $\begin{array}{l}\text { TSH, fT3, fT4, aTPO and aTG } \\
\text { levels } \\
\text { Serum selenium } \\
\text { concentration } \\
\text { Ultrasound thyroid image } \\
\text { The number of lymphocytes } \\
\text { in smear from fine-needle } \\
\text { aspiration biopsy of the } \\
\text { thyroid (the sub-group of } \\
18 \text { patients) }\end{array}$ & $\begin{array}{l}\text { 1. No significant changes in aTPO } \\
\text { concentrations and lympocyte numbers } \\
\text { from biopsy in the selenium taking groups } \\
\text { 2. A significant decrease of aTG } \\
\text { concentrations after } 3 \text { and } 6 \text { months in the } \\
\text { selenium taking groups } \\
\text { 3. TSH, fT3 and fT4 - without any } \\
\text { significant changes }\end{array}$ \\
\hline $\begin{array}{l}\text { Deng et al. } \\
\text { Chinese Gen } \\
\text { Practice } \\
\text { (2013) [138] }\end{array}$ & $\begin{array}{l}94 \text { patients with } \\
\text { CAT ( } 81 \text { women } \\
\text { and } 13 \text { men) }\end{array}$ & $\begin{array}{l}6 \text { months; } \\
\text { RCS }\end{array}$ & $\begin{array}{l}200 \mu \mathrm{g} \text { of selenium (n } \\
=48 ; \text { including } 7 \text { men) } \\
\text { Placebo ( } \mathrm{n}=46 ; \\
\text { including } 6 \text { men) } \\
\text { The initial mean } \\
\text { concentration of } \\
\text { selenium in serum - } \\
\text { no data }\end{array}$ & $\begin{array}{l}\text { TSH, fT3, fT4 levels } \\
\text { aTP0, aTG levels } \\
\text { Ultrasound thyroid image }\end{array}$ & $\begin{array}{l}\text { In comparison with the control group: } \\
\text { decreased levels of antibodies } \\
\text { reduced goitre size and smaller focal } \\
\text { changes }\end{array}$ \\
\hline $\begin{array}{l}\text { Zhang et } \\
\text { al. Medical } \\
\text { Innov. of } \\
\text { China (2013) } \\
\text { [139] }\end{array}$ & $\begin{array}{l}66 \text { patients with } \\
\text { CAT ( } 61 \text { women } \\
\text { and } 5 \text { men) }\end{array}$ & $\begin{array}{l}3 \text { months; } \\
\text { RCS }\end{array}$ & $\begin{array}{l}\mathrm{L}-\mathrm{T} 4+200 \mu \mathrm{g} \text { of yeast } \\
\text { selenium ( } \mathrm{n}=46 \text {; } \\
\text { including } 4 \text { men) } \\
\mathrm{L-T} 4+\text { placebo ( } \mathrm{n}= \\
20 ; \text { including } 1 \text { man) } \\
\text { The initial mean } \\
\text { concentration of } \\
\text { selenium in serum - } \\
\text { no data }\end{array}$ & $\begin{array}{l}\text { TSH, fT3, fT4 concentrations } \\
\text { aTPO, aTG levels }\end{array}$ & $\begin{array}{l}\text { 1. Significant drop of aTPO concentrations } \\
\text { in both groups, no difference between them } \\
\text { 2. No aTG concentration changes }\end{array}$ \\
\hline $\begin{array}{l}\text { Eskes et al. } \\
\text { Clin Endocrinol } \\
\text { (0xf) (2014) } \\
{[140]}\end{array}$ & $\begin{array}{l}61 \text { women } \\
\text { with CAT in } \\
\text { euthyreosis } \\
\text { and without } \\
\text { treatment with } \\
\text { L-T4 }\end{array}$ & $\begin{array}{l}9 \text { months; } \\
\text { RCS }\end{array}$ & $\begin{array}{l}200 \mu \mathrm{g} \text { of sodium } \\
\text { selenate for } 6 \text { months } \\
\text { ( } \mathrm{n}=30 \text { ) } \\
\text { Placebo for } 6 \text { months } \\
\text { ( } \mathrm{n}=31 \text { ) } \\
\text { The initial mean } \\
\text { concentration of } \\
\text { selenium in serum- } \\
72.9 \text { and } 74.7 \mu \mathrm{g} / \mathrm{L}\end{array}$ & $\begin{array}{l}\text { TSH, fT4, aTPO levels } \\
\text { Selenium and SPP1 } \\
\text { concentrations in serum } \\
\text { Quality of life }\end{array}$ & $\begin{array}{l}\text { 1. Neither significant changes of TSH, ft4 } \\
\text { and aTPO in the groups nor differences } \\
\text { among them } \\
\text { 2. No differences among the groups, regarding } \\
\text { the quality of life of the patients }\end{array}$ \\
\hline $\begin{array}{l}\text { Calissendorff } \\
\text { et al. Eur } \\
\text { Thyroid J } \\
\text { (2015) [141] }\end{array}$ & $\begin{array}{l}38 \text { patients with } \\
\text { Graves' disease } \\
\text { ( } 31 \text { women) }\end{array}$ & $\begin{array}{l}9 \text { months; } \\
\text { RCS }\end{array}$ & $\begin{array}{l}30 \mathrm{mg} \text { of methimazole } \\
+100 \mu \mathrm{g} \text { of L-T4 } \\
+200 \mu \mathrm{g} \text { of } \\
\text { selenomethionine / day } \\
\text { (15 women and } 4 \text { men) } \\
30 \mathrm{mg} \text { of methimazole } \\
+100 \mu \mathrm{g} \text { of L-T4 / day } \\
\text { (16 women and } 3 \text { men) } \\
\text { No selenium } \\
\text { concentration assays, } \\
\text { SPP concentration in } \\
\text { serum }-47 \mathrm{ng} / \mathrm{mL} \text { and } \\
49.5 \mathrm{ng} / \mathrm{mL}\end{array}$ & $\begin{array}{l}\text { TSH, fT3, fT4 concentrations } \\
\text { aTSHR, aTPO levels } \\
\text { SPP concentration in serum } \\
\text { Well-being studies } \\
\text { (depression and anxiety } \\
\text { indices) }\end{array}$ & $\begin{array}{l}\text { 1. Results in Group 1: } \\
\text { — significantly lower fT4 values after } 18 \\
\text { and } 36 \text { weeks and higher TSH values } \\
\text { after } 18 \text { weeks } \\
\text { — negative correlation between } \\
\text { depression index and fT3 and positive } \\
\text { correlation between depression index } \\
\text { and TSH } \\
\text { 2. No significant differences among } \\
\text { the groups, regarding aTPO and aTSHR } \\
\text { concentrations and well-being indices }\end{array}$ \\
\hline
\end{tabular}


Table II (cont.). Main characteristics of major clinical studies concerning the relationship between selenium and benign thyroid diseases

\begin{tabular}{|c|c|c|c|c|c|}
\hline $\begin{array}{l}\text { Pilli i wsp. } \\
\text { Eur Thyroid J } \\
\text { (2015) [142] }\end{array}$ & $\begin{array}{l}60 \text { women with } \\
\text { CAT, not treated } \\
\text { with L-T4 and in } \\
\text { euthyreosis }\end{array}$ & $\begin{array}{l}12 \text { months; } \\
\text { RCS }\end{array}$ & $\begin{array}{l}\text { Placebo }(\mathrm{n}=20) \\
80 \mu \mathrm{g} \text { of } \\
\text { selenomethionine } \\
(\mathrm{n}=20) \\
160 \mu \mathrm{g} \\
\text { selenomethionine } \\
(\mathrm{n}=20) \\
\text { The initial mean } \\
\text { concentration of } \\
\text { selenium in serum - } \\
81.8 \mu \mathrm{g} / \mathrm{L}\end{array}$ & $\begin{array}{l}\text { TSH, fT3, fT4 concentrations } \\
\text { aTP0, aTG levels } \\
\text { Serum selenium } \\
\text { concentration } \\
\text { Ultrasound thyroid image } \\
\text { Concentrations of selected } \\
\text { cytokines and chemokines } \\
\text { Quality of life }\end{array}$ & $\begin{array}{l}\text { 1. No significant changes in aTPO } \\
\text { concentrations in selenium taking groups } \\
\text { 2. A significant drop of aTG } \\
\text { concentrations in the group of patients, } \\
\text { taking } 160 \mu \mathrm{g} \text { of selenium and placebo } \\
\text { after } 12 \text { months } \\
\text { 3. No significant changes in the sonographic } \\
\text { picture of the thyroid gland and in the } \\
\text { quality of life in and among the groups } \\
\text { 4. CXCL- } 9 \text { and }-10 \text { chemokine concentrations } \\
\text { decreased after } 6 \text { and } 12 \text { months of } \\
\text { selenomethionine administration, whereas } \\
\text { they did not change in the control group }\end{array}$ \\
\hline $\begin{array}{l}\text { Farias et al. } \\
\text { J Endocrinol } \\
\text { Invest (2015) } \\
\text { [143] }\end{array}$ & $\begin{array}{l}55 \text { patients } \\
\text { with chronic } \\
\text { autoimmune } \\
\text { thyroiditis (CAT) } \\
\text { ( } 50 \text { women and } \\
5 \text { men) }\end{array}$ & $\begin{array}{l}6 \text { months; } \\
\text { RCS }\end{array}$ & $\begin{array}{l}200 \mu \mathrm{g} \text { of } \\
\text { selenomethionine for } \\
3 \text { months ( } 26 \text { women } \\
\text { and } 2 \text { men) } \\
\text { Placebo for } 3 \text { months } \\
\text { ( } 24 \text { women and } 3 \text { men) } \\
\text { The initial mean } \\
\text { concentration of selenium } \\
\text { in serum - no access } \\
\text { to data }\end{array}$ & $\begin{array}{l}\text { Selenium and GP1 } \\
\text { concentrations in serum } \\
\text { aTPO levels } \\
\text { Ultrasound thyroid image }\end{array}$ & $\begin{array}{l}\text { Significant decrease of aTPO concentration } \\
\text { after } 6 \text { months of the observation, without } \\
\text { any analogous changes in the placebo } \\
\text { group }\end{array}$ \\
\hline $\begin{array}{l}\text { Wang et al. } \\
\text { Horm Metab } \\
\text { Res. (2016) } \\
{[144]}\end{array}$ & $\begin{array}{l}41 \text { patients } \\
\text { with recurrent } \\
\text { Graves' disease } \\
\text { (34 women and } \\
7 \text { men) }\end{array}$ & $\begin{array}{l}6 \text { months } \\
+ \text { follow } \\
\text { up; } \\
\text { RCS or } \\
\text { quasi-RCS }\end{array}$ & $\begin{array}{l}\text { Methimazole (18 } \\
\text { women and } 2 \text { men) } \\
\text { Methimazole }+200 \mu \mathrm{g} \\
\text { of sodium selenite } \\
\text { (16 women and } 5 \text { men) } \\
\text { The initial mean } \\
\text { concentration of } \\
\text { selenium in serum - } \\
\text { no access to data }\end{array}$ & $\begin{array}{l}\text { TSH, fT3, fT4, aTSHR } \\
\text { concentrations } \\
\text { The percent of remissions }\end{array}$ & $\begin{array}{l}\text { Results in Group 2: } \\
\text { — significantly lower fT3 and fT4 and } \\
\text { higher TSH after } 2 \text { months of therapy } \\
\text { — significantly higher aTSHR level after } \\
\text { 6-month supplementation (assayed at } \\
\text { follow-up visit) } \\
\text { — significantly higher percent of aTSHR } \\
\text { normalisation after } 6 \text { months } \\
\text { (19\% vs. 0\%) } \\
\text { — significantly higher chance to achieve } \\
\text { remission in selenium taking patients }\end{array}$ \\
\hline
\end{tabular}

CAT — chronic autoimmune thyroiditis; RCS — randomised clinical study; NRCS — non-randomised clinical study — open label; GP1 — glutathione peroxidase 1; SPP — P selenoprotein

after 12 months, already after selenium withdrawal, were analogous to those obtained before [145]. The results, as presented above, have contributed to the inclusion of selenium supplementation in the recommendations of European Group on Graves' orbitopathy (EUGOGO), issued in 2016, according to which, in benign forms of short-term thyroid orbitopathy, the use of sodium selenate is recommended twice daily in dose of $100 \mu \mathrm{g}$ for six months [146], although its use was already encouraged before that [147]. Two interesting clinical trials are currently underway [148, 149], the results of which may bring us closer to a more conclusive answer to the question of whether supplementation with selenium significantly influences the state of patients with Graves' disease [148] and the quality of life of patients with CAT [149].

Selenium plays a significant role in the maintenance of homeostasis of the human body. Selenoproteins protect the body against damage exerted by oxidative stress, including lesions in the TG, and are responsible for its physiological activity and adequate hormonal production. The issue of selenium supplementation for primary and secondary prophylactic purposes, regarding various structural and functional disorders of the TG, remains an open question and requires further studies. Taking into account the data from the presented clinical studies, one should consider the application of selenium supplementation in autoimmune diseases of the TG, including the widespread Hashimoto disease. Patients who are in the population with selenium deficit may especially benefit, as well as persons in whom selenium deficit is confirmed by selenium concentration assay in plasma. One should then consider the cost-effectiveness of such an approach and the possible implementation of such studies into diagnostic algorithms. However, the rather narrow therapeutic 
index of selenium should be taken into account, as well as the risk associated with acute and chronic overdose, in particular, the increased risk for development of diabetes mellitus type 2 . In consideration of the increased demands for selenium in pregnancy, the benefits should also be considered, which could be achieved as a result of selenium supplementation in pregnant women and, possibly, appropriate recommendations should be defined, similar as those formulated for iodine [150]. At present, a six-month supplementation with $200 \mu \mathrm{g}$ of selenium is recommended in mild forms of shortterm thyroid ophthalmopathy, taking into account its measurable clinical benefits.

\section{References}

1. Rayman MP, Rayman MP. The importance of selenium to human health Lancet. 2000; 356(9225): 233-241, doi: 10.1016/S0140-6736(00)02490-9 indexed in Pubmed: 10963212.

2. Hoffmann PR, Berry MJ. The influence of selenium on immune responses. Mol Nutr Food Res. 2008; 52(11): 1273-1280, doi: 10.1002 mnfr.200700330, indexed in Pubmed: 18384097.

3. Holben DH, Smith AM. The diverse role of selenium within selenoproteins: a review. J Am Diet Assoc. 1999; 99(7): 836-843, doi: 10.1016/ S0002-8223(99)00198-4, indexed in Pubmed: 10405682.

4. Kieliszek M, Błażejak S. Selenium: Significance, and outlook for supplementation. Nutrition. 2013; 29(5): 713-718, doi: 10.1016/j.nut.2012.11.012 indexed in Pubmed: 23422539.

5. Slencu BG, Ciobanu C, Cuciureanu R. Selenium content in foodstuff and its nutritional requirement forhumans. Clujul Med. ; 2012: 139-145.

6. Dietary re, vitamin E. selenium, and carotenoids: A report of the Panel on Dietary Antioxidants and Related Compounds, Subcommittees on Upper Reference Levels of Nutrients and Interpretation and Uses of Dietary Reference Intakes, and the Standing Committee on the Scientific Evaluation of Dietary Reference Intakes, Food and Nutrition Board, Institute of Medicine. Washington, D.C. : National Academy Press. ; 2000.

7. Navarro-Alarcon M, Cabrera-Vique C. Selenium in food and the human body: a review. Sci Total Environ. 2008; 400(1-3): 115-141, doi: 10.1016/i. scitotenv.2008.06.024, indexed in Pubmed: 18657851.

8. Alfthan G, Eurola M, Ekholm P, et al. Selenium Working Group. Effects of nationwide addition of selenium to fertilizers on foods, and animal and human health in Finland: From deficiency to optimal selenium status of the population. J Trace Elem Med Biol. 2015; 31: 142-147, doi: 10.1016/j.jtemb.2014.04.009, indexed in Pubmed: 24908353.

9. Fairweather-Tait SJ, Collings R, Hurst R. Selenium bioavailability: current knowledge and future research requirements. Am J Clin Nutr. 2010; 91(5): 1484S-1491S, doi: 10.3945/ajcn.2010.28674J, indexed in Pubmed: 20200264.

10. Wasowicz W, Gromadzinska J, Rydzynski K, et al. Selenium status of low-selenium area residents: Polish experience. Toxicol Lett. 2003; 137(1 2): 95-101, indexed in Pubmed: 12505435.

11. Jablonska E, Gromadzinska J, Klos A, et al. Original research article. Journal of Food Composition and Analysis. 2013; 31: 259-65.

12. Schrauzer GN, White DA. Selenium in human nutrition: dietary intakes and effects of supplementation. Bioinorg Chem. 1978; 8(4): 303-318, indexed in Pubmed: 647060 .

13. Combs GF. Selenium in global food systems. Br J Nutr. 2001; 85(5): 517-547, indexed in Pubmed: 11348568.

14. Patterson $\mathrm{BH}$, Levander OA. Naturally occurring selenium compounds in cancer chemoprevention trials: a workshop summary. Cancer Epidemiol Biomarkers Prev. 1997; 6(1): 63-69, indexed in Pubmed: 8993799.

15. Zagrodzki P, Laszczyk P. [Selenium and cardiovascular disease: selected issues]. Postepy Hig Med Dosw (Online). 2006; 60: 624-631, indexed in Pubmed: 17199104.

16. Fordyce F. Selenium Geochemistry and Health. AMBIO: Journal of the Human Environment. 2007; 36(1): 94-97, doi: 10.1579/0044-7447(2007)36[94:sgah]2.0.co;2.

17. Dumont E, Vanhaecke F, Cornelis R. Selenium speciation from food source to metabolites: a critical review. Anal Bioanal Chem. 2006; 385(7): 1304-1323, doi: 10.1007/s00216-006-0529-8, indexed in Pubmed: 16830114

18. Davis TZ, Tiwary AK, Stegelmeier BL, et al. Comparative oral dose toxicokinetics of sodium selenite and selenomethionine. J Appl Toxicol. 2017; 37(2): 231-238, doi: 10.1002/jat.3350, indexed in Pubmed: 27283737.
19. Pérez-Corona MT, Sánchez-Martínez M, Valderrama MJ, et al. Selenium biotransformation by Saccharomyces cerevisiae and Saccharomyces bayanus during white wine manufacture: Laboratory-scale experiments. Food Chemistry. 2011; 124(3): 1050-1055, doi: 10.1016/j.foodchem.2010.07.073.

20. Burk RF, Norsworthy BK, Hill KE, et al. Effects of chemical form of selenium on plasma biomarkers in a high-dose human supplementation trial. Cancer Epidemiol Biomarkers Prev. 2006; 15(4): 804-810, doi: 10.1158/1055-9965.EPI-05-0950, indexed in Pubmed: 16614127.

21. Combs GF, Watts JC, Jackson MI, et al. Determinants of selenium status in healthy adults. Nutr J. 2011; 10: 75, doi: 10.1186/1475-2891-10-75, indexed in Pubmed: 21767397.

22. Hollenbach B, Morgenthaler NG, Struck J, et al. New assay for the measurement of selenoprotein $\mathrm{P}$ as a sepsis biomarker from serum. J Trace Elem Med Biol. 2008; 22(1): 24-32, doi: 10.1016/j.jtemb.2007.11.003, indexed in Pubmed: 18319137.

23. Burk RF, Hill KE. Selenoprotein P: an extracellular protein with unique physical characteristics and a role in selenium homeostasis. Annu Rev Nutr. 2005; 25: 215-235, doi: 10.1146/annurev.nutr.24.012003.132120, indexed in Pubmed: 16011466.

24. Hoeflich J, Hollenbach B, Behrends T, et al. The choice of biomarkers determines the selenium status in young German vegans and vegetarians. Br J Nutr. 2010; 104(11): 1601-1604, doi: 10.1017/S0007114510002618, indexed in Pubmed: 20637135

25. Hurst R, Armah CN, Dainty JR, et al. Establishing optimal selenium status: results of a randomized, double-blind, placebo-controlled trial. Am J Clin Nutr. 2010; 91(4): 923-931, doi: 10.3945/ajcn.2009.28169, indexed in Pubmed: 20181815.

26. Mistry HD, Broughton Pipkin F, Redman CWG, et al. Selenium in reproductive health. Am J Obstet Gynecol. 2012; 206(1): 21-30, doi: 10.1016/j. ajog.2011.07.034, indexed in Pubmed: 21963101.

27. Li S, Xiao T, Zheng B. Medical geology of arsenic, selenium and thallium in China. Sci Total Environ. 2012; 421-422: 31-40, doi: 10.1016/j. scitotenv.2011.02.040, indexed in Pubmed: 21440288

28. Pedrero Z, Madrid Y. Novel approaches for selenium speciation in foodstuffs and biological specimens: a review. Anal Chim Acta. 2009; 634(2): 135-152, doi: 10.1016/j.aca.2008.12.026, indexed in Pubmed: 19185112.

29. Suetens C, Moreno-Reyes R, Chasseur C, et al. Epidemiological support for a multifactorial aetiology of Kashin-Beck disease in Tibet. Int Orthop. 2001; 25(3): 180-187, indexed in Pubmed: 11482537.

30. Chen J. An original discovery: selenium deficiency and Keshan disease (an endemic heart disease). Asia Pac J Clin Nutr. 2012; 21(3): 320-326, indexed in Pubmed: 22705420.

31. Yao Y, Pei F, Kang P. Selenium, iodine, and the relation with KashinBeck disease. Nutrition. 2011; 27(11-12): 1095-1100, doi: 10.1016/j. nut.2011.03.002, indexed in Pubmed: 21967994.

32. Hendrickx W, Decock J, Mulholland F, et al Selenium Biomarkers in Prostate Cancer Cell Lines and Influence of Selenium on Invasive Potential of PC3 Cells. Front Oncol. 2013; 3: 239, doi: 10.3389/fonc.2013.00239, indexed in Pubmed: 24066278.

33. Ruseva B, Himcheva I, Nankova D. Importance of selenoproteins for the function of the thyroid gland. Medicine. 2013; 3: 60-64.

34. Roman M, Jitaru P, Barbante C. Selenium biochemistry and its role for human health. Metallomics. 2014; 6(1): 25-54, doi: 10.1039/c3mt00185g indexed in Pubmed: 24185753.

35. Letavayová L, Vlasáková D, Spallholz J, et al. Toxicity and mutagenicity of selenium compounds in Saccharomyces cerevisiae. Mutation Research/ Fundamental and Molecular Mechanisms of Mutagenesis. 2008; 638(1-2): 1-10, doi: $10.1016 / \mathrm{j} . \mathrm{mrfmmm} .2007 .08 .009$.

36. Fordyce F. Selenium Deficiency and Toxicity in the Environment. Essentials of Medical Geology. 2012: 375-416, doi: 10.1007/978-94-007-4375-5 16.

37. Nazemi L, Nazmara S, Eshraghyan MR, et al. Selenium status in soil, water and essential crops of Iran. Iranian J Environ Health Sci Eng. 2012; 9(1): 11, doi: 10.1186/1735-2746-9-11, indexed in Pubmed: 23369199.

38. Drutel A, Archambeaud F, Caron P. Selenium and the thyroid gland: more good news for clinicians. Clin Endocrinol (Oxf). 2013; 78(2): 155-164, doi: 10.1111/cen.12066, indexed in Pubmed: 23046013.

39. Rayman MP. The use of high-selenium yeast to raise selenium status: how does it measure up? Br J Nutr. 2004; 92(4): 557-573, indexed in Pubmed: $\underline{15522125}$

40. Zwolak I, Zaporowska H. Selenium interactions and toxicity: a review. Selenium interactions and toxicity. Cell Biol Toxicol. 2012; 28(1): 31-46, doi: 10.1007/s10565-011-9203-9, indexed in Pubmed: 21913064.

41. Dharmasena A. Selenium supplementation in thyroid associated ophthalmopathy: an update. Int J Ophthalmol. 2014; 7(2): 365-375, doi: 10.3980/i.issn.2222-3959.2014.02.31 indexed in Pubmed: 24790886.

42. Muller FL, Lustgarten MS, Jang Y, et al. Trends in oxidative aging theories. Free Radic Biol Med. 2007; 43(4): 477-503, doi: 10.1016/j.freeradbiomed.2007.03.034, indexed in Pubmed: 17640558.

43. Berry MJ, Banu L, Chen YY, et al. Recognition of UGA as a selenocysteine codon in type I deiodinase requires sequences in the $3^{\prime}$ untranslated region. Nature. 1991; 353(6341): 273-276, doi: 10.1038/353273a0, indexed in Pubmed: 1832744. 
44. Köhrle J, Jakob F, Contempré B, et al. Selenium, the thyroid, and the endocrine system. Endocr Rev. 2005; 26(7): 944-984, doi: 10.1210/er.20010034, indexed in Pubmed: 16174820.

45. Arthur JR, Nicol F, Beckett GJ. Hepatic iodothyronine 5 -deiodinase. The role of selenium. Biochemical Journal. 1990; 272(2): 537-540, doi: 10.1042/bj2720537.

46. Behne D, Kyriakopoulos A, Meinhold H, et al. Identification of type I iodothyronine 5'-deiodinase as a selenoenzyme. Biochem Biophys Res Commun. 1990; 173(3): 1143-1149, indexed in Pubmed: 2268318.

47. Rosen BP, Liu Z. Transport pathways for arsenic and selenium: a minireview. Environ Int. 2009; 35(3): 512-515, doi: 10.1016/j.envint.2008.07.023, indexed in Pubmed: 18789529.

48. Tamura T,Stadtman TC. A new selenoprotein from human lung adenocarcinoma cells: purification, properties, and thioredoxin reductase activity. Proc Natl Acad Sci U S A. 1996; 93(3): 1006-1011, indexed in Pubmed: 8577704.

49. Pappa EC, Pappas AC, Surai PF. Selenium content in selected foods from the Greek market and estimation of the daily intake. Sci Total Environ. 2006; 372(1): 100-108, doi: 10.1016/j.scitotenv.2006.08.008, indexed in Pubmed: 16959300.

50. Rayman M. Selenium and human health. The Lancet. 2012; 379(9822): 1256-1268, doi: 10.1016/s0140-6736(11)61452-9.

51. Cagliani R, Fruguglietti ME, Berardinelli A, et al. New molecular findings in congenital myopathies due to selenoprotein $\mathrm{N}$ gene mutations. J Neurol Sci. 2011; 300(1-2): 107-113, doi: 10.1016/j.jns.2010.09.011, indexed in Pubmed: 20937510.

52. Brozmanová J, Mániková D, Vlčková V, et al. Selenium: a double-edged sword for defense and offence in cancer. Arch Toxicol. 2010; 84(12): 919-938, doi: 10.1007/s00204-010-0595-8, indexed in Pubmed: 20871980.

53. Papp LV, Lu J, Holmgren A, et al. From selenium to selenoproteins: synthesis, identity, and their role in human health. Antioxid Redox Signal. 2007; 9(7): 775-806, doi: 10.1089/ars.2007.1528, indexed in Pubmed: 17508906

54. Kamwesiga J, Mutabazi V, Kayumba J, et al. Effect of selenium supplementation on CD4+ T-cell recovery, viral suppression and morbidity of HIV-infected patients in Rwanda. AIDS. 2015; 29(9): 1045-1052, doi: 10.1097/qad.0000000000000673.

55. Lipinski B. Can Selenite be an Ultimate Inhibitor of Ebola and Other Viral Infections? British Journal of Medicine and Medical Research. 2015; 6(3): 319-324, doi: 10.9734/bjmmr/2015/14858.

56. Kawai K, Meydani SN, Urassa W, et al. Micronutrient supplementation and $\mathrm{T}$ cell-mediated immune responses in patients with tuberculosis in Tanzania. Epidemiol Infect. 2014; 142(7): 1505-1509, doi: 10.1017/ S0950268813002495, indexed in Pubmed: 24093552.

57. Solovyev ND. Importance of selenium and selenoprotein for brain function: From antioxidant protection to neuronal signalling. J Inorg Biochem. 2015; 153: 1-12, doi: 10.1016/j.jinorgbio.2015.09.003, indexed in Pubmed: 26398431.

58. IMS Institute for Healthcare Informatics. Medicine use and shifting costs of healthcare: a review of the use of medicines in the United States in 2013. www.imshealth.com

59. Biron VL, Bang H, Farwell DG, et al. National Trends and Factors Associated with Hospital Costs Following Thyroid Surgery. Thyroid. 2015; 25(7): 823-829, doi: 10.1089/thy.2014.0495, indexed in Pubmed: 25873398.

60. Nexo MA, Watt T, Pedersen J, et al. Increased risk of long-term sickness absence, lower rate of return to work, and higher risk of unemployment and disability pensioning for thyroid patients: a Danish register-based cohort study. J Clin Endocrinol Metab. 2014; 99(9): 3184-3192, doi: 10.1210/jc.2013-4468, indexed in Pubmed: 24937367.

61. Cooper R, Pinkney J, Ayling RM. Appropriateness of prescribing thyroxine in primary care. Ann Clin Biochem. 2015; 52(Pt 4): 497-501, doi: 10.1177/0004563214568686, indexed in Pubmed: 25575699.

62. Hess SY. The impact of common micronutrient deficiencies on iodine and thyroid metabolism: the evidence from human studies. Best Pract Res Clin Endocrinol Metab. 2010; 24(1): 117-132, doi: 10.1016/j. beem.2009.08.012, indexed in Pubmed: 20172476.

63. Yu X, Shan Z, Li C, et al. Iron deficiency, an independent risk factor for isolated hypothyroxinemia in pregnant and nonpregnant women of childbearing age in China. J Clin Endocrinol Metab. 2015; 100(4): 1594-1601, doi: 10.1210/jc.2014-3887, indexed in Pubmed: 25599388.

64. Knudsen N, Brix TH. Genetic and non-iodine-related factors in the aetiology of nodular goitre. Best Pract Res Clin Endocrinol Metab. 2014; 28(4): 495-506, doi: 10.1016/j.beem.2014.02.005, indexed in Pubmed: 25047201

65. Jain RB. Thyroid function and serum copper, selenium, and zinc in general U.S. population. Biol Trace Elem Res. 2014; 159(1-3): 87-98, doi: 10.1007/s12011-014-9992-9, indexed in Pubmed: 24789479.

66. Zimmermann MB. The influence of iron status on iodine utilization and thyroid function. Annu Rev Nutr. 2006; 26: 367-389, doi: 10.1146/annurev. nutr.26.061505.111236, indexed in Pubmed: 16602928.

67. Jain RB, Choi YS. Interacting effects of selected trace and toxic metals on thyroid function. Int J Environ Health Res. 2016; 26(1): 75-91, doi: 10.1080/09603123.2015.1020416, indexed in Pubmed: 25788177.
68. Contempre B, Dumont JE, Denef JF, et al. Effects of selenium deficiency on thyroid necrosis, fibrosis and proliferation: a possible role in myxoedematous cretinism. Eur J Endocrinol. 1995; 133(1): 99-109, indexed in Pubmed: 7627345 .

69. Schomburg L, Köhrle J. On the importance of selenium and iodine metabolism for thyroid hormone biosynthesis and human health. Mol Nutr Food Res. 2008; 52(11): 1235-1246, doi: 10.1002/mnfr.200700465, indexed in Pubmed: 18686295.

70. Liu Y, Huang H, Zeng J, et al. Thyroid volume, goiter prevalence, and selenium levels in an iodine-sufficient area: a cross-sectional study. BMC Public Health. 2013; 13: 1153, doi: 10.1186/1471-2458-13-1153, indexed in Pubmed: 24321191.

71. Contempre B, Le Moine O, Dumont JE, et al. Selenium deficiency and thyroid fibrosis. A key role for macrophages and transforming growth factor beta (TGF-beta). Mol Cell Endocrinol. 1996; 124(1-2): 7-15, indexed in Pubmed: $\underline{9027319}$.

72. Xu J, Liu XL, Yang XF, et al. Supplemental selenium alleviates the toxic effects of excessive iodine on thyroid. Biol Trace Elem Res. 2011; 141(1-3): 110-118, doi: 10.1007/s12011-010-8728-8, indexed in Pubmed: 20517655.

73. Azevedo MF, Barra GB, Naves LA, et al. Selenoprotein-related disease in a young girl caused by nonsense mutations in the SBP2 gene. J Clin Endocrinol Metab. 2010; 95(8): 4066-4071, doi: 10.1210/jc.2009-2611, indexed in Pubmed: 20501692.

74. Dumitrescu AM, Liao XH, Abdullah MSY, et al. Mutations in SECISBP2 result in abnormal thyroid hormone metabolism. Nat Genet. 2005 37(11): 1247-1252, doi: $10.1038 /$ ng1654, indexed in Pubmed: 16228000.

75. Hamajima T, Mushimoto Y, Kobayashi H, et al. Novel compound heterozygous mutations in the SBP2 gene: characteristic clinical manifestations and the implications of $\mathrm{GH}$ and triiodothyronine in longitudinal bone growth and maturation. Eur J Endocrinol. 2012; 166(4): 757-764 doi: 10.1530/EJE-11-0812, indexed in Pubmed: 22247018.

76. Schoenmakers E, Agostini M, Mitchell C, et al. Mutations in the selenocysteine insertion sequence-binding protein 2 gene lead to a multisystem selenoprotein deficiency disorder in humans. J Clin Invest. 2010; 120(12): 4220-4235, doi: 10.1172/JCI43653, indexed in Pubmed: 21084748.

77. Hatfield DL, Tsuji PA, Carlson BA, et al. Selenium and selenocysteine: roles in cancer, health, and development. Trends Biochem Sci. 2014; 39(3): 112-120, doi: 10.1016/j.tibs.2013.12.007, indexed in Pubmed: 24485058.

78. Labunskyy VM, Hatfield DL, Gladyshev VN. Selenoproteins: Molecular Pathways and Physiological Roles. Physiol Rev. 2014; 94(3): 739-777, doi: 10.1152/physrev.00039.2013.

79. Köhrle J. Pathophysiological relevance of selenium. J Endocrinol Invest. 2013; 36(10 Suppl): 1-7, indexed in Pubmed: 24419053.

80. Contempré B, Duale NL, Dumont JE, et al. Effect of selenium supplementation on thyroid hormone metabolism in an iodine and selenium deficient population. Clin Endocrinol (Oxf). 1992; 36(6): 579-583, indexed in Pubmed: 1424183.

81. Contempré B, de Escobar GM, Denef JF, et al. Thiocyanate induces cell necrosis and fibrosis in selenium- and iodine-deficient rat thyroids: a potential experimental model for myxedematous endemic cretinism in central Africa. Endocrinology. 2004; 145(2): 994-1002, doi: 10.1210 en.2003-0886, indexed in Pubmed: 14500569.

82. Turanov AA, Shchedrina VA, Everley RA, et al. Selenoprotein $\mathrm{S}$ is involved in maintenance and transport of multiprotein complexes. Biochem J. 2014; 462(3): 555-565, doi: 10.1042/BJ20140076, indexed in Pubmed: 24897171

83. Schomburg L. Selenium, selenoproteins and the thyroid gland: interactions in health and disease. Nat Rev Endocrinol. 2011; 8(3): 160-171, doi: 10.1038/nrendo.2011.174, indexed in Pubmed: 22009156.

84. Shchedrina VA, Zhang Y, Labunskyy VM, et al. Structure-function relations, physiological roles, and evolution of mammalian ER-resident selenoproteins. Antioxid Redox Signal. 2010; 12(7): 839-849, doi: 10.1089/ ars.2009.2865, indexed in Pubmed: 19747065.

85. Rijntjes E, Scholz PM, Mugesh G, et al. Se- and s-based thiouracil and methimazole analogues exert different inhibitory mechanisms on type 1 and type 2 deiodinases. Eur Thyroid J. 2013; 2(4): 252-258, doi: 10.1159/000355288, indexed in Pubmed: 24783056

86. Bhowmick D, Srivastava S, D'Silva P, et al. Highly Efficient Glutathione Peroxidase and Peroxiredoxin Mimetics Protect Mammalian Cells against Oxidative Damage. Angew Chem Int Ed Engl. 2015; 54(29): 8449-8453, doi: 10.1002/anie.201502430, indexed in Pubmed: 26032473 .

87. Manna D, Roy G, Mugesh G. Antithyroid drugs and their analogues: synthesis, structure, and mechanism of action. Acc Chem Res. 2013 46(11): 2706-2715, doi: 10.1021/ar4001229, indexed in Pubmed: 23883148.

88. Raja K, Mugesh G. Remarkable effect of chalcogen substitution on an enzyme mimetic for deiodination of thyroid hormones. Angew Chem Int Ed Engl. 2015; 54(26): 7674-7678, doi: 10.1002/anie.201502762, indexed in Pubmed: 25968052.

89. Weissel M. Propylthiouracil: clinical overview of its efficacy and its side effects more than 50 years after the introduction of its use in thyrostatic treatment. Exp Clin Endocrinol Diabetes. 2010; 118(2): 101-104, doi: 10.1055/s-0029-1215587, indexed in Pubmed: 19449281. 
90. Gershengorn MC, Neumann S. Update in TSH receptor agonists and antagonists. J Clin Endocrinol Metab. 2012; 97(12): 4287-4292, doi: 10.1210/jc.2012-3080, indexed in Pubmed: 23019348.

91. Derumeaux H, Valeix P, Castetbon K, et al. Association of selenium with thyroid volume and echostructure in 35- to 60-year-old French adults. Eur J Endocrinol. 2003; 148(3): 309-315, indexed in Pubmed: 12611611.

92. Rasmussen LB, Schomburg L, Köhrle J, et al. Selenium status, thyroid volume, and multiple nodule formation in an area with mild iodine deficiency. Eur J Endocrinol. 2011; 164(4): 585-590, doi: 10.1530/EJE-101026, indexed in Pubmed: 21242171.

93. Bülow Pedersen I, Knudsen N, Carlé A, et al. Serum selenium is low in newly diagnosed Graves' disease: a population-based study. Clin Endocrinol (Oxf). 2013; 79(4): 584-590, doi: 10.1111/cen.12185, indexed in Pubmed: 23448365.

94. Li H, Li J. Thyroid disorders in women. Minerva Med. 2015; 106(2): 109-114, indexed in Pubmed: 25668600.

95. Schomburg L, Schweizer U. Hierarchical regulation of selenoprotein expression and sex-specific effects of selenium. Biochim Biophys Acta. 2009; 1790(11): 1453-1462, doi: 10.1016/j.bbagen.2009.03.015, indexed in Pubmed: 19328222.

96. Riese C, Michaelis M, Mentrup B, et al. Selenium-dependent pre- and posttranscriptional mechanisms are responsible for sexual dimorphic expression of selenoproteins in murine tissues. Endocrinology. 2006; 147(12): 5883-5892, doi: 10.1210/en.2006-0689, indexed in Pubmed: 16959840.

97. Stoedter M, Renko K, Hög A, et al. Selenium controls the sex-specific immune response and selenoprotein expression during the acute-phase response in mice. Biochem J. 2010; 429(1): 43-51, doi: 10.1042/BJ20091868 indexed in Pubmed: 20370716.

98. Combs GF, Midthune DN, Patterson KY, et al. Effects of selenomethionine supplementation on selenium status and thyroid hormone concentrations in healthy adults. Am J Clin Nutr. 2009; 89(6): 1808-1814, doi: 10.3945/ajcn.2008.27356, indexed in Pubmed: 19403637.

99. Pellegriti G, Frasca F, Regalbuto C, et al. Worldwide increasing incidence of thyroid cancer: update on epidemiology and risk factors. J Cance Epidemiol. 2013; 2013: 965212, doi: 10.1155/2013/965212, indexed in Pubmed: 23737785.

100. Colonna M, Uhry Z, Guizard AV, et al. FRANCIM network. Recent trends in incidence, geographical distribution, and survival of papillary thyroid cancer in France. Cancer Epidemiol. 2015; 39(4): 511-518, doi: 10.1016/j. canep.2015.04.015, indexed in Pubmed: 26003877.

101. Davies L, Welch HG. Current thyroid cancer trends in the United States. JAMA Otolaryngol Head Neck Surg. 2014; 140(4): 317-322, doi: 10.1001 jamaoto.2014.1, indexed in Pubmed: 24557566.

102. Davis CD, Tsuji PA, Milner JA. Selenoproteins and cancer prevention. Annu Rev Nutr. 2012; 32: 73-95, doi: 10.1146/annurev-nutr-071811-150740, indexed in Pubmed: 22404120.

103. Glattre E, Thomassen Y, Thoresen SO, et al. Prediagnostic serum selenium in a case-control study of thyroid cancer. Int J Epidemiol. 1989; 18(1): 45-49, indexed in Pubmed: 2722382.

104. Kucharzewski M, Braziewicz J, Majewska U, et al. Concentration of selenium in the whole blood and the thyroid tissue of patients with various thyroid diseases. Biol Trace Elem Res. 2002; 88(1): 25-30, doi: 10.1385/BTER:88:1:25, indexed in Pubmed: 12117262

105. Moncayo R, Kroiss A, Oberwinkler M, et al. The role of selenium, vitamin $\mathrm{C}$, and zinc in benign thyroid diseases and of selenium in malignant thyroid diseases: Low selenium levels are found in subacute and silent thyroiditis and in papillary and follicular carcinoma. BMC Endocr Disord. 2008; 8: 2, doi: 10.1186/1472-6823-8-2, indexed in Pubmed: 18221503.

106. Przybylik-Mazurek E, Zagrodzki P, Kuźniarz-Rymarz S, et al. Thyroid disorders-assessments of trace elements, clinical, and laboratory parameters. Biol Trace Elem Res. 2011; 141(1-3): 65-75, doi: 10.1007/s12011-0108719-9, indexed in Pubmed: 20455027.

107. Jonklaas J, Danielsen M, Wang H. A pilot study of serum selenium, vitamin $\mathrm{D}$, and thyrotropin concentrations in patients with thyroid cancer Thyroid. 2013; 23(9): 1079-1086, doi: 10.1089/thy.2012.0548, indexed in Pubmed: 23350941.

108. O'Grady TJ, Kitahara CM, DiRienzo AG, et al. The association between selenium and other micronutrients and thyroid cancer incidence in the NIH-AARP Diet and Health Study. PLoS One. 2014; 9(10): e110886, doi 10.1371/journal.pone.0110886, indexed in Pubmed: 25329812.

109. Shen F, Cai WS, Li JL, et al. The Association Between Serum Levels of Selenium, Copper, and Magnesium with Thyroid Cancer: a Meta-analysis. Biol Trace Elem Res. 2015; 167(2): 225-235, doi: 10.1007/s12011-015-0304-9, indexed in Pubmed: 25820485.

110. Baltaci AK, Dundar TK, Aksoy F, et al. Changes in the Serum Levels of Trace Elements Before and After the Operation in Thyroid Cancer Patients. Biol Trace Elem Res. 2017; 175(1): 57-64, doi: 10.1007/s12011016-0768-2, indexed in Pubmed: 27263537.

111. Chung HK, Nam JiS, Ahn CW, et al. Some Elements in Thyroid Tissue are Associated with More Advanced Stage of Thyroid Cancer in Korean Women. Biol Trace Elem Res. 2016; 171(1): 54-62, doi: 10.1007/s12011015-0502-5, indexed in Pubmed: 26419761.
112. Becker NP, Martitz J, Renko K, et al. Hypoxia reduces and redirects selenoprotein biosynthesis. Metallomics. 2014; 6(5): 1079-1086, doi: 10.1039/c4mt00004h, indexed in Pubmed: 24700164.

113. Hesse-Bähr K, Dreher I, Köhrle J. The influence of the cytokines Il-1beta and INFgamma on the expression of selenoproteins in the human hepatocarcinoma cell line HepG2. Biofactors. 2000; 11(1-2): 83-85, indexed in Pubmed: 10705969.

114. Renko K, Hofmann PJ, Stoedter M, et al. Down-regulation of the hepatic selenoprotein biosynthesis machinery impairs selenium metabolism during the acute phase response in mice. FASEB J. 2009; 23(6): 1758-1765, doi: 10.1096/fj.08-119370, indexed in Pubmed: 19136613.

115. Dreher I, Jakobs TC, Köhrle J. Cloning and characterization of the human selenoprotein P promoter. Response of selenoprotein P expression to cytokines in liver cells. J Biol Chem. 1997; 272(46): 29364-29371, indexed in Pubmed: 9361018.

116. Xue H, Wang W, Li Y, et al. Selenium upregulates CD4(+)CD25(+) regulatory $\mathrm{T}$ cells in iodine-induced autoimmune thyroiditis model of NOD.H-2(h4) mice. Endocr J. 2010; 57(7): 595-601, indexed in Pubmed: 20453397.

117. Huang Z, Rose AH, Hoffmann PR. The role of selenium in inflammation and immunity: from molecular mechanisms to therapeutic opportunities. Antioxid Redox Signal. 2012; 16(7): 705-743, doi: 10.1089/ ars.2011.4145, indexed in Pubmed: 21955027.

118. Tan L, Sang ZNa, Shen J, et al Selenium supplementation alleviates autoimmune thyroiditis by regulating expression of TH1/TH2 cytokines. Biomed Environ Sci. 2013; 26(11): 920-925, doi: 10.3967/bes2013.022, indexed in Pubmed: 24331538.

119. Hawkes WC, Richter D, Alkan Z. Dietary selenium supplementation and whole blood gene expression in healthy North American men. Biol Trace Elem Res. 2013; 155(2): 201-208, doi: 10.1007/s12011-013-9786-5, indexed in Pubmed: 23955482

120. Toulis KA, Anastasilakis AD, Tzellos TG, et al. Selenium supplementation in the treatment of Hashimoto's thyroiditis: a systematic review and a meta-analysis. Thyroid. 2010; 20(10): 1163-1173, doi: 10.1089/ thy.2009.0351, indexed in Pubmed: 20883174

121. Mao J, Pop VJ, Bath SC, et al. Effect of low-dose selenium on thyroid autoimmunity and thyroid function in UK pregnant women with mildto-moderate iodine deficiency. Eur J Nutr. 2016; 55(1): 55-61, doi: 10.1007/ s00394-014-0822-9, indexed in Pubmed: 25524327.

122. Negro R, Greco G, Mangieri T, et al. The influence of selenium supplementation on postpartum thyroid status in pregnant women with thyroid peroxidase autoantibodies. J Clin Endocrinol Metab. 2007; 92(4): 1263-1268, doi: 10.1210/jc.2006-1821, indexed in Pubmed: 17284630.

123. van Zuuren EJ, Albusta AY, Fedorowicz Z, et al. Selenium supplementation for Hashimoto's thyroiditis. Cochrane Database Syst Rev. 2013(6) CD010223, doi: 10.1002/14651858.CD010223.pub2, indexed in Pubmed: 23744563.

124. Köhrle J, Gärtner R. Selenium and thyroid. Best Pract Res Clin Endocrino Metab. 2009; 23(6): 815-827, doi: 10.1016/j.beem.2009.08.002, indexed in Pubmed: $\underline{19942156}$

125. Rayman MP, Thompson AJ, Bekaert B, et al. Randomized controlled tria of the effect of selenium supplementation on thyroid function in the elderly in the United Kingdom. Am J Clin Nutr. 2008; 87(2): 370-378, indexed in Pubmed: 18258627.

126. Fan Y, Xu S, Zhang H, et al. Selenium supplementation for autoimmune thyroiditis: a systematic review and meta-analysis. Int J Endocrinol. 2014; 2014: 904573, doi: 10.1155/2014/904573, indexed in Pubmed 25574167.

127. Gärtner R, Gasnier BCH, Dietrich JW, et al. Selenium supplementation in patients with autoimmune thyroiditis decreases thyroid peroxidase antibodies concentrations. J Clin Endocrinol Metab. 2002; 87(4): 1687-1691, doi: 10.1210/icem.87.4.8421, indexed in Pubmed: 11932302.

128. Gärtner R, Gasnier B. Selenium in the treatment of autoimmune thyroiditis. BioFactors. 2003; 19(3-4): 165-170, doi: 10.1002/biof.5520190309.

129. Duntas LH, Mantzou $E$ Koutras DA. Effects of a six month treatment with selenomethionine in patients with autoimmune thyroiditis. Eur J Endocrinol. 2003; 148(4): 389-393, indexed in Pubmed: 12656658.

130. Turker O, Kumanlioglu K, Karapolat I, et al. Selenium treatment in autoimmune thyroiditis: 9-month follow-up with variable doses. J Endocrinol. 2006; 190(1): 151-156, doi: 10.1677/joe.1.06661, indexed in Pubmed: 16837619 .

131. Mazokopakis EE, Papadakis JA, Papadomanolaki MG, et al. Effects of 12 months treatment with L-selenomethionine on serum anti-TPO Levels in Patients with Hashimoto's thyroiditis. Thyroid. 2007; 17(7): 609-612, doi: 10.1089/thy.2007.0040, indexed in Pubmed: 17696828 .

132. Karanikas G, Schuetz M, Kontur S, et al. No immunological benefit of selenium in consecutive patients with autoimmune thyroiditis. Thyroid. 2008; 18(1): 7-12, doi: 10.1089/thy.2007.0127, indexed in Pubmed: 18302514.

133. Bonfig W, Gärtner R, Schmidt H. Selenium supplementation does not decrease thyroid peroxidase antibody concentration in children and adolescents with autoimmune thyroiditis. ScientificWorldJournal. 2010 10: 990-996, doi: 10.1100/tsw.2010.91, indexed in Pubmed: 20526530. 
134. Nacamulli D, Mian C, Petricca D, et al. Influence of physiological dietary selenium supplementation on the natural course of autoimmune thyroiditis. Clin Endocrinol (Oxf). 2010; 73(4): 535-539, doi: 10.1111/j.13652265.2009.03758.x, indexed in Pubmed: 20039895.

135. Krysiak R, Okopien B. The effect of levothyroxine and selenomethionine on lymphocyte and monocyte cytokine release in women with Hashimoto's thyroiditis. J Clin Endocrinol Metab. 2011; 96(7): 2206-2215, doi: 10.1210/jc.2010-2986, indexed in Pubmed: 21508145.

136. Onal H, Keskindemirci G, Adal E, et al. Effects of selenium supplementation in the early stage of autoimmune thyroiditis in childhood: an openlabel pilot study. J Pediatr Endocrinol Metab. 2012; 25(7-8): 639-644, doi: 10.1515/jpem-2012-0078, indexed in Pubmed: 23155687.

137. Anastasilakis AD, Toulis KA, Nisianakis P, et al. Selenomethionine treatment in patients with autoimmune thyroiditis: a prospective, quasirandomised trial. Int J Clin Pract. 2012; 66(4): 378-383, doi: 10.1111/j.17421241.2011.02879.x, indexed in Pubmed: 22356267.

138. Deng SY, Chen XY, Wu LY, et al. Influence of seleniumon Hashimoto thyroiditis with normal thyroid function. Chinese General Practice. 2013; 70: 2483-2485.

139. Zhang W, Wang JF, Li JL, et al. The effect of seleniumon thyroid peroxidase antibody and thyroglobulin antibody in Hashimoto thyroiditis. Medical Innovation of China. 2013; 10: 13-14

140. Eskes SA, Endert E, Fliers E, et al. Selenite supplementation in euthyroid subjects with thyroid peroxidase antibodies. Clin Endocrinol (Oxf). 2014; 80(3): 444-451, doi: 10.1111/cen.12284, indexed in Pubmed: 23844613.

141. Calissendorff J, Mikulski E, Larsen EH, et al. A Prospective Investigation of Graves' Disease and Selenium: Thyroid Hormones, Auto-Antibodies and Self-Rated Symptoms. Eur Thyroid J. 2015; 4(2): 93-98, doi: 10.1159/000381768, indexed in Pubmed: 26279994.

142. Pilli T, Cantara S, Schomburg L, et al. IFN $\gamma$-Inducible Chemokines Decrease upon Selenomethionine Supplementation in Women with Euthyroid Autoimmune Thyroiditis: Comparison between Two Doses of Selenomethionine $(80$ or $160 \mu \mathrm{g})$ versus Placebo. Eur Thyroid J. 2015; 4(4): 226-233, doi: 10.1159/000439589, indexed in Pubmed: 26835425.
143. de Farias CR, Cardoso BR, de Oliveira GMB, et al. A randomized-controlled, double-blind study of the impact of selenium supplementation on thyroid autoimmunity and inflammation with focus on the GPx1 genotypes. J Endocrinol Invest. 2015; 38(10): 1065-1074, doi: 10.1007/ s40618-015-0285-8, indexed in Pubmed: 25894865.

144. Wang L, Wang B, Chen SR, et al. Effect of Selenium Supplementation on Recurrent Hyperthyroidism Caused by Graves' Disease: A Prospective Pilot Study. Horm Metab Res. 2016; 48(9): 559-564, doi: 10.1055/s-0042110491, indexed in Pubmed: 27392116.

145. Marcocci C, Kahaly GJ, Krassas GE, et al. European Group on Graves Orbitopathy. Selenium and the course of mild Graves' orbitopathy. N Engl J Med. 2011; 364(20): 1920-1931, doi: 10.1056/NEJMoa1012985, indexed in Pubmed: 21591944.

146. Bartalena L, Baldeschi L, Boboridis K, et al. European Group on Graves' Orbitopathy (EUGOGO). The 2016 European Thyroid Association/ European Group on Graves' Orbitopathy Guidelines for the Management of Graves' Orbitopathy. Eur Thyroid J. 2016; 5(1): 9-26, doi: 10.1159/000443828, indexed in Pubmed: 27099835.

147. Ruchała M, Hernik A, Zybek A. Orbital radiotherapy in the management of Graves' orbitopathy--current state of knowledge. Endokrynol Pol. 2014; 65(5): 388-396, doi: 10.5603/EP.2014.0054, indexed in Pubmed: 25301490.

148. Watt T, Cramon P, Bjorner JB, et al. Selenium supplementation for patients with Graves' hyperthyroidism (the GRASS trial): study protoco for a randomized controlled trial. Trials. 2013; 14: 119, doi: 10.1186/17456215-14-119, indexed in Pubmed: 23782950.

149. Winther KH, Watt T, Bjørner JB, et al. The chronic autoimmune thyroiditis quality of life selenium trial (CATALYST): study protocol for a randomized controlled trial. Trials. 2014; 15: 115, doi: $\underline{10.1186 / 1745-}$ 6215-15-115, indexed in Pubmed: 24716668.

150. Zygmunt A, Adamczewski Z, Zygmunt A, et al. An assessment of the effectiveness of iodine prophylaxis in pregnant women--analysis in one of reference gynaecological-obstetric centres in Poland. Endokrynol Pol. 2015; 66(5): 404-411, doi: 10.5603/EP.2015.0050, indexed in Pubmed: 26457494. 


\title{
Rola selenu w patofizjologii gruczołu tarczowego
}

\author{
Michat Stuss ${ }^{1,2}$, Marta Michalska-Kasiczak', Ewa Sewerynek ${ }^{1,2}$ \\ ${ }^{1}$ Zakład Zaburzeń Endokrynnych i Metabolizmu Kostnego, Katedra Endokrynologii UM w Łodzi, Polska \\ ${ }^{2}$ Poradnia Endokrynologiczna i Leczenia Osteoporozy Regionalnego Ośrodka Menopauzy i Osteoporozy Uniwersyteckiego Szpitala \\ Klinicznego im. WAM-CSW w Łodzi, Polska
}

Artykuł jest tłumaczeniem pracy: Stuss M., Michalska-Kasiczak M., Sewerynek E., The role of selenium in thyroid gland pathophysiology. Endokryno Pol 2017; 69 (4): 440-454

Należy cytować wersję pierwotną.

Piśmiennictwo dostępne w wersji pierwotnej na stronach 451-454

\begin{abstract}
Streszczenie
Obecnie uważa się, że dla właściwego funkcjonowania gruczołu tarczowego (GT), oprócz jodu niezbędne są również: selen, żelazo, cynk, miedź oraz wapń. Niejednokrotnie dopiero adekwatna podaż jednego z tych mikroelementów (na przykład jodu), może ujawnić objawy wynikające z niedoboru pozostałych (na przykład żelaza lub selenu).

Selen jest zaliczany do pierwiastków śladowych mających kluczowe znaczenie dla utrzymania homeostazy organizmu ludzkiego, szczególnie dla prawidłowego funkcjonowania układu odpornościowego i tarczycy. Wyniki badań epidemiologicznych wykazały, że niedobór selenu może dotyczyć aż 1 miliarda ludzi na całym świecie i wielu krajów. Warto również podkreślić istotne zależności, które narzucają odpowiednią kolejność suplementacji. Wykazano bowiem, że nadmierna podaż dużych dawek selenu może w rejonach endemicznych nasilać skutki niedoboru jodu, podczas gdy odpowiednia podaż selenu u badanych zwierząt może lagodzić konsekwencje nadmiaru jodu, zapobiegając zmianom destrukcyjno-zapalnym tarczycy. (Endokrynol Pol 2017; 68 (4): 455-465)

Niniejszy artykuł stanowi podsumowanie aktualnego stanu wiedzy na temat roli selenu w funkcjonowaniu GT.

Słowa kluczowe: selen, gruczoł tarczowy, tarczyca, suplementacja
\end{abstract}

\section{Wstęp}

Selen jest zaliczany do pierwiastków śladowych mających kluczowe znaczenie dla utrzymania homeostazy organizmu ludzkiego, szczególnie dla prawidłowego funkcjonowania układu odpornościowego [1, 2]. Wyniki badań epidemiologicznych wykazały, że niedobór selenu może dotyczyć aż 1 miliarda ludzi na całym świecie i wielu krajów [3].

\section{Dawki selenu i źródła}

Według zaleceń Światowej Organizacji Zdrowia (WHO, ang. World Health Organization) podaż tego mikroelementu nie powinna przekraczać $70 \mu \mathrm{g} /$ dobę, a dzienne spożycie powyżej 400-700 $\mu$ g może wywierać działanie toksyczne [4]. Zgodnie z zaleceniami opublikowanymi przez Food and Nutrition Board of the National Academy of Science mężczyźni powinni spożywać 40-70 $\mu \mathrm{g}$

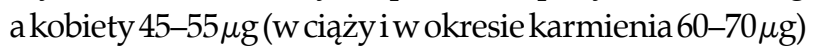
selenu dziennie $[5,6]$. Jak wykazały badania populacyjne średnie dobowe spożycie selenu w krajach eu- ropejskich wynosi 20-70 $\mu \mathrm{g} /$ dobę [1, 5, 7-9], a w Polsce 20-59 $\mu$ g dziennie $[10,11]$. Z kolei według 30-dniowej obserwacji innych badaczy typowa dieta przeciętnego Amerykanina dostarcza codziennie od 90 do $168 \mu \mathrm{g}$ tego pierwiastka [12]. W niektórych regionach Chin szacuje się, że spożycie selenu sięga wartości nawet $5 \mathrm{mg}$ /dobę [10,13]. Aby zapewnić odpowiednio szeroki margines bezpieczeństwa, w niektórych źródłach możemy spotkać się z pojęciem dawki referencyjnej selenu (ang. Reference Dose; RfD), która według Pattersona i Levandera wynosi $350 \mu \mathrm{g}$ dziennie, co odpowiada podaży około $5 \mu \mathrm{g} / \mathrm{kg}$ masy ciała człowieka. Zgodnie z założeniem autorów $150 \mu \mathrm{g}$ selenu dziennie powinien zapewnić pokarm a pozostałe $200 \mu \mathrm{g}$ suplementy [14].

Rozważając zatem zastosowanie suplementacji selenu należy mieć świadomość jego wąskiego indeksu terapeutycznego i możliwości wystąpienia nieprzyjemnych działań niepożądanych, nie tylko w przypadku stosowania suplementów diety, ale także pokarmów w niego obfitujących [15]. Wykazano, że spożycie dużej ilości owoców pewnych roślin, między innymi z gatunku Lecythis ollaria może powodować u ludzi wypadanie 
włosów, nudności, wymioty i biegunkę [16]. Zawartość selenu, w tych samych produktach pochodzących $\mathrm{z}$ różnych regionów może się znacznie różnić, co ma związek z klimatem, ilością tego pierwiastka w glebie oraz zdolnością roślin do jego magazynowania, co z kolei ma bezpośrednie przełożenie na wyższe ogniwa łańcuchów pokarmowych [17]. Wysoką zawartością selenu charakteryzują się pokarmy wysokobiałkowe, orzechy — w szczególności brazylijskie (ponad $6 \mu \mathrm{g} / \mathrm{g}$ produktu) oraz grzyby, między innymi pieczarki i drożdże (te ostatnie nawet do $3 \mathrm{mg} / \mathrm{g}$ ). Warzywa i owoce $\mathrm{z}$ reguły zawierają małe ilości tego mikroelementu (często znacznie poniżej $0,5 \mu \mathrm{g} / \mathrm{g}$ produktu), co ma związek z wysoką zawartością wody i niską białka, jednakże niektóre $z$ nich mogą stanowić dobre źródła selenu, między innymi czosnek, brokuły, kapusta, kalafior i kalarepa [5].

Selen $\mathrm{w}$ formie naturalnej najczęściej występuje $\mathrm{w}$ postaci organicznej: selenometioniny, metyloselenocysteiny lub $\gamma$-glutamylometyloselenocysteiny. Z kolei produkty wzbogacone i suplementy, oprócz związków organicznych (selenoaminokwasów) często zawierają sole nieorganiczne zwłaszcza selenu (IV) [18]. Uważa się, że selen organiczny jest lepiej przyswajalny, a doskonałym substratem do produkcji jego suplementów są drożdże [19]. Wykazano, że w jelicie wchłanianiu ulega średnio 85-95\% dawki organicznych związków selenu, podczas gdy związków nieorganicznych średnio 10\%. Po wniknięciu do krwi selen ulega związaniu z erytrocytami oraz globulinami i albuminami osocza i w takiej postaci jest transportowany do różnych tkanek i narządów. Największe jego ilości stwierdza się $\mathrm{w}$ wątrobie, nerkach, jądrach, tarczycy, trzustce i przysadce, a także we włosach i paznokciach. Największą zawartością selenu, w porównaniu z innymi narządami charakteryzują się mięśnie (nawet połowa zmagazynowanego pierwiastka). Do oceny zaopatrzenia organizmu w selen możemy zastosować pomiar stężeń białek zawierających ten mikroelement, między innymi selenoproteiny P1 (SPP1) lub peroksydazy glutationu (PG). Ze względu na istotną rolę selenoprotein w utrzymaniu homeostazy organizmu zaleca się, aby stężenia tych białek były możliwie wysokie. Ustalono, że peroksydaza glutationu 3 uzyskuje stan plateau przy stężeniu około $125 \mu \mathrm{U} / 1$, które odzwierciedla stężenie selenu w surowicy około $1 \mu \mathrm{M} / \mathrm{l}(79 \mu \mathrm{g} / \mathrm{l})$, które z kolei zapewnia średnia podaż $125 \mu \mathrm{g}$ tego pierwiastka dziennie [20-24]. Z kolei najwyższe stężenia selenoproteiny $\mathrm{P}$ uzyskiwano przy stężeniach selenu w zakresie 110-125 $\mu \mathrm{g} / \mathrm{l}$ w surowicy [25]. W literaturze można spotkać się z różnymi zakresami wartości referencyjnych stężenia selenu w surowicy, w zależności od regionu geograficznego, kraju a także grupy etnicznej, co ma związek z dietą.

\section{Problem niedoboru selenu}

Skutki niedoboru selenu możemy obserwować w rejonach geograficznych, gdzie stwierdzono obecność gleby ubogiej w ten pierwiastek, takich jak Syberia i większa część obszaru Chin [16, 26, 27]. Objawy niedoboru selenu dotyczą wielu organów i układów i są związane ze zmniejszoną aktywnością, upośledzeniem funkcji i struktury białek związanych z tym mikroelementem, tak zwanych selenoprotein [28]. Do najczęściej opisywanych w literaturze należą: kardiomiopatia rozstrzeniowa (choroba Keshan) oraz endemiczna osteoartropatia (choroba Kashina-Becka) [28-30].

Choroba Keshan najczęściej występuje u kobiet w wieku reprodukcyjnym i dzieci do 10. roku życia [30]. Z kolei, choroba Kashina-Becka charakteryzuje się zmianami przypominającymi reumatoidalne zapalenie stawów, skróceniem palców dłoni i stóp oraz zaburzeniami wzrastania. $Z$ powodu zwiększonego nasilenia procesów oksydacyjnych dochodzi do uszkodzenia i martwicy chrząstek i deformacji kostnych. Choroba dotyczy najczęściej dzieci do 13. roku życia [7, 29]. Do wystąpienia/nasilenia objawów choroby Kashina-Becka przyczynia się współwystępowanie niedoboru jodu $[29,31]$.

Z innych znamiennych skutków niedoboru selenu warto wymienić: niewydolność krążenia, zaburzenia rytmu serca, udary, zespół nagłej śmierci niemowląt, niepłodność u mężczyzn, raka prostaty, nefropatię oraz nasilenie objawów chorób związanych z układem odpornościowym i autoimmunologicznych, między innymi tarczycy [26, 32-34].

\section{Problem nadmiaru selenu}

Analogicznie do niedoboru, również nadmiar selenu najczęściej spotyka się na obszarach geograficznych, gdzie występuje z kolei duża zawartość selenu w glebie, między innymi w niektórych regionach Indii.

Duże dawki selenu indukują zwiększoną produkcję wolnych rodników, powodujących uszkodzenie DNA. Ponadto, nadmiar selenu inaktywuje białka odpowiedzialne za naprawę uszkodzonego DNA, wykazując wysokie powinowactwo do ich grup tiolowych [35].

Nadmierne spożycie selenu wywołuje klasyczne objawy zatrucia: osłabienie organizmu, nudności, wymioty oraz biegunke, a ponadto zaburzenia neurologiczne np. ataksję $[7,36]$. Przewlekle zwiększona podaż selenu powoduje chorobę zwaną selenozą, objawiającą się: uszkodzeniem wątroby, zaburzeniami krwiotworzenia, wypadaniem włosów, niepłodnością, wysypką, pękaniem paznokci, nieprzyjemnym zapachem $\mathrm{z}$ ust (przypominającym zapach czosnku) oraz różnymi zaburzeniami neurologicznymi [7, 27, 37]. 
Warto również podkreślić negatywny wpływ nadmiaru selenu na układ wewnątrzwydzielniczy, obejmujący upośledzenie syntezy hormonów tarczycy (HT) i hormonu wzrostu oraz pierwszego insulinopodobnego czynnika wzrostu (ang. Insulin-like Growth Factor-1; IGF-1) [7]. Wykazano także, że jego nadmierna podaż może zwiększać ryzyko wystąpienia cukrzycy typu 2 [38]. Ponadto wdychanie związków selenu może przyczyniać się do wystąpienia chemicznego zapalenia oskrzeli i płuc (nawet obrzęku płuc), podrażnienia oczu oraz bólów głowy. Dane kliniczne dotyczące dawek przy których mogą występować objawy uboczne nie są jednoznaczne. W badaniu populacji chińskiej wykazano, że zwiększona częstość selenozy wiąże się ze stosowaniem dawek tego mikroelementu powyżej $850 \mu \mathrm{g} /$ dobę [26]. Z kolei, u pacjentów z reumatoidalnym zapaleniem stawów dzienna podaż $600 \mu \mathrm{g}$ selenu uzyskanego z drożdży przyczyniła się do zmniejszenia nasilenia bólu stawów, przy braku objawów zatrucia selenem [39]. W innym badaniu pacjenci otrzymujący około $700 \mu \mathrm{g}$ selenu dziennie dobrze tolerowali tę dawkę [40]. Zdaniem wielu autorów największe korzyści z suplementacji selenem odnoszą osoby, u których podaż tego pierwiastka jest obniżona. $W$ innych przypadkach należy brać pod uwagę zwiększone ryzyko wystąpienia zaburzeń metabolicznych [38, 41].

\section{Jak działa selen?}

Jak już wcześniej wspomniano, atomy selenu wchodzą w skład tak zwanych selenoprotein oraz enzymów antyoksydacyjnych, między innymi: PG, tioredoksynoreduktaz (TRR), dejodynaz jodotyroninowych (DJ), SPP1 i selenoproteiny W. Peroksydaza glutationu była pierwszą opisaną selenoproteiną, jednak do tej pory zidentyfikowano 8 izoform tego enzymu, różniących się budową i miejscem występowania [42]. Głównym zadaniem PG jest ochrona błon lipidowych przed stresem oksydacyjnym. Katalizują one reakcje redukcji nadtlenku wodoru $\left(\mathrm{H}_{2} \mathrm{O}_{2}\right)$ oraz nadtlenków organicznych $(\mathrm{ROOH}), \mathrm{z}$ wytworzeniem kwasu selenawego jako pólproduktu lub odpowiednich alkoholi [33].

Wyróżnia się trzy typy dejodynaz jodotyroninowych. Pełnią one kluczową rolę $w$ aktywacji pozostałych form HT do najbardziej aktywnej trijodotyroniny (T3) (typ 1 i 2), a ponadto $w$ inaktywacji tyroksyny i T3 (typ 3) [43-46]. Wyżej wymieniona grupa enzymów pełni zatem kluczową rolę we właściwym funkcjonowaniu tarczycy, a także jej rozwoju [47]. W sytuacji niedoboru selenu upośledzeniu ulega metabolizm jodu, co przyczynia się do zaburzeń syntezy HT, a to może mieć przełożenie na stan kliniczny i samopoczucie pacjentów [34].

Tioredoksynoreduktazy pod względem biochemicznym odpowiadają za reakcję redukcji utlenionej tioredoksyny. Enzymy tej grupy stanowią dawcę elektronu dla innych ważnych enzymów oksydoredukcyjnych, np. reduktazy rybonukleotydowej i peroksydazy tioredoksyny. Same tioredoksyny wykazują właściwości inhibitorów apoptozy, czynników wzrostu oraz reduktorów hydroperoksydazy. Dodatkowo reduktaza tioredoksyny może redukować utleniony glutation, kwas dehydroaskorbinowy, witaminę K, nadtlenki lipidów oraz nadtlenek wodoru [48].

Selenoproteina P1 oprócz roli magazynu i transportera selenu w organizmie pełni także rolę chelatora metali ciężkich, poprzez tworzenie z nimi nietoksycznych kompleksów oraz może wywierać działanie przeciwnowotworowe $[49,50]$. Selenoproteina $W$ odpowiada za metabolizm układu mięśniowego, a $\mathrm{N}$ za rozwój mięśni $[3,51]$. Wykazano, że określone mutacje genu dla selenoproteiny $\mathrm{N}$, mogą powodować miopatię multiminicore [51]. Zidentyfikowano również inne selenoproteiny S, M [47, 52, 53], jednakże ich rola nie została jeszcze dokładnie poznana.

Wspomniano już wcześniej, że selen może regulować funkcjonowanie układu immunologicznego $[1,2]$. Wykazano, że wyżej wymieniony pierwiastek może stymulować syntezę przeciwcial, zwłaszcza IgG i IgM oraz aktywować limfocyty T i makrofagi [38]. Udowodniono także, że związki zawierające selen mogą hamować transformację zakażenia wirusem HIV do pełnoobjawowego AIDS [54]. Selen wywiera także właściwości przeciwwirusowe i antybakteryjne oraz hamuje progresję różnych postaci wirusowego zapalenia wątroby, a nawet może zapobiegać infekcji niektórymi RNA wirusami, między innymi wirusem Ebola $[1,2,55,56]$.

Postulowane właściwości przeciwnowotworowe selenu, w dużej mierze opierają się na jego wspomnianych już właściwościach antyoksydacyjnych. Warto także wspomnieć o jego korzystnym wpływie na aktywację limfocytów NK [50]. Do tej pory opisano jego pozytywne właściwości w kontekście raka jelita grubego, gruczołu krokowego oraz płuc [52]. Pojawily się także doniesienia na temat roli selenu w przewodnictwie impulsów w ośrodkowym układzie nerwowym (OUN) [1, 57]. Ponadto, wspomniany mikroelement może zapobiegać cukrzycy, chorobom układu krążenia i niepłodności [26, 32].

\section{Selen a gruczoł tarczowy}

Choroby tarczycy uważane są za jedne z częstszych ogólem i zdecydowanie najczęstsze problemy natury endokrynologicznej, z jakimi pacjenci zgłaszają się do lekarza [58-60]. Z kolei L-tyroksyna znajduje się $\mathrm{w}$ pierwszej dziesiątce powszechnie przyjmowanych i najczęściej przepisywanych leków [58, 61]. 
Obecnie uważa się, że dla właściwego funkcjonowania gruczołu tarczowego (GT), oprócz jodu niezbędne są również: selen, żelazo, cynk, miedź oraz wapń [44, 62-67]. Niejednokrotnie dopiero adekwatna podaż jednego z tych mikroelementów (na przykład jodu), może ujawnić objawy wynikające $z$ niedoboru pozostałych (na przykład żelaza lub selenu) [62, 63, 66]. Warto również podkreślić istotne zależności, które narzucają odpowiednią kolejność suplementacji. Wykazano bowiem, że nadmierna podaż dużych dawek selenu może $\mathrm{w}$ rejonach endemicznych nasilać skutki niedoboru jodu, podczas gdy odpowiednia podaż selenu u badanych zwierząt może łagodzić konsekwencje nadmiaru jodu, zapobiegając zmianom destrukcyjno-zapalnym tarczycy [44, 68-72]. Tarczyca podobnie jak jądra i mózg, w porównaniu do pozostałych narządów ludzkiego organizmu, cechuje się wysoką zawartością selenu, nawet pomimo jego ciężkiego niedoboru w organizmie [44]. $\mathrm{O}$ istotnej roli selenu $\mathrm{w}$ metabolizmie tarczycy mogą świadczyć badania pacjentów dotkniętych mutacjami białka wiążącego sekwencje SECIS (ang. Selenocysteine insertion sequence (SECIS) binding protein 2; SBP2), które ma istotne znaczenie dla syntezy selenoprotein. Zaobserwowano, że rozmaite mutacje genu dla wyżej wymienionego białka powodują między innymi wystąpienie charakterystycznej konfiguracji hormonalnej: podwyższonego stężenia TSH, fT4 i obniżonego fT3 oraz niedosłuchu odbiorczego, a ponadto bardziej charakterystycznych cech takich, jak: upośledzenia rozwoju układu kostnego, miopatii, zaburzeń rozwoju OUN w zakresie zdolności motorycznych, nadwrażliwości na promieniowanie UV oraz wzmożonej insulinowrażliwości [73-76].

Jak już wcześniej wspomniano, wszystkie dejodynazy jodotyroninowe, a także inne białka, między innymi PG i TRR zawierają atomy selenu. Wykazano wysoką aktywność tych enzymów w obrębie tkanki tarczycowej, jednakże do utrzymania katalizowanego przez dejodynazy metabolizmu jodu, na odpowiednim poziomie wystarczy ich niewielka aktywność, znacznie mniejsza niż innych selenoprotein w szlakach metabolicznych przemian białek, tłuszczów i aminokwasów [34, 77, 78]. A zatem stężenie selenu lub zawierających go białek w surowicy nie znajduje bezpośredniego przełożenia na zawartość selenu w tarczycy i aktywność zawartych w niej selenoprotein [69, 79]. W dostępnej literaturze brak jest także danych odnośnie mierzalnych parametrów, które w sposób jednoznaczny i wiarygodny odzwierciedlały zaopatrzenie tarczycy w selen.

Wielu istotnych danych klinicznych na temat roli suplementacji selenu w homeostazie GT dostarczyły badania przeprowadzone w latach 80 -tych w Afryce Centralnej. U zamieszkującej tę część kontynentu ludności obserwowano objawy kretynizmu z obrzękiem śluzowatym, objawiających się między innymi upośledzeniem umysłowym, zahamowaniem wzrostu i dojrzewania płciowego, które jak wykazały badania miały związek z niedoborem jodu i selenu oraz spożyciem dużych ilości pokarmów zawierających związki wolotwórcze (goitrogenów) [44, 80]. Niekorzystny efekt addytywny niedoboru obu mikroelementów potwierdzają także wyniki badań na zwierzętach [80, 81]. Za związane z niedoborem selenu uszkodzenie i zwłóknienie tkanki tarczycy odpowiada najprawdopodobniej transformujący czynnik wzrostu $\beta$ (ang. Transforming Growth Factor $\beta$; TGF $\beta$ ), który pośredniczy w stymulacji uszkodzeń wywołanych stresem oksydacyjnym i zainicjowanych wysokimi stężeniami TSH [71]. Z kolei odpowiednia podaż selenu zapobiega opisanym procesom, nawet $\mathrm{w}$ sytuacji wysokiej podaży jodu, po uprzednim długo trwającym niedoborze [68, 71, $72,80]$. Jak wykazały badania w Zairze, zastosowanie suplementacji selenem, bez uprzedniego wyrównania niedoboru jodu może pogorszyć funkcjonowanie tarczycy pacjenta, dlatego zaleca się wcześniejsze uzupełnienie niedoboru jodu [80]. Za mechanizm tego zjawiska uważa się wzrost aktywności dejodynaz, zwiększony obrót HT i ich nasiloną dejodynację, a także utratę jodu z moczem [44]. Opisana powyżej sytuacja kliniczna była opisywana tylko w ciężkim niedoborze obu pierwiastków.

Istnieje szereg hipotez dotyczących protekcyjnej roli selenu w chorobach tarczycy. Aktualnie uważa się, że odpowiednia podaż selenu, może [41]:

1. Zmniejszać ekspresję antygenów HLA-DR na powierzchni tyreocytów.

2. Wpływać na obniżenie stężeń przeciwciał przeciwko antygenom tarczycy.

3. Regulować odpowiedź immunologiczną zależną od limfocytów B.

4. Hamować produkcję prozapalnych cytokin.

5. Zmniejszać syntezę leukotrienów i prostaglandyn.

6. Chronić tarczycę przed stresem oksydacyjnym

7. Optymalizować syntezę i transport HT, poprzez indukcję syntezy selenoprotein (między innymi p15 i S) [82-84].

$\mathrm{W}$ ostatnich latach powstało nawet kilka zawierających selen analogów tyreostatyków oraz związków naśladujących działanie selenoprotein [85-88]. Leki przeciwtarczycowe aktualnie dostępne na rynku mogą powodować szereg nieprzyjemnych objawów ubocznych [89], a zatem możliwość synergistycznego działania na zahamowanie nie tylko biosyntezy ale również aktywacji HT lub samej tylko ich aktywacji, mogłaby okazać się nową cenną opcją terapeutyczną dla pacjentów z nadczynnością tarczycy o różnej etiologii, która dodatkowo byłaby pozbawiona objawów ubocznych wywoływanych przez aktualnie dostępne leki [90]. 
W jednym z pierwszych badań interwencyjnych, w którym zastosowano suplementację różnych witamin i mikroelementów wykazano, że zbyt mała podaż selenu wpływa na wzrost objętości GT jedynie u kobiet [91]. Analogiczne wyniki uzyskano badając populację duńską, gdzie stwierdzono także odwrotną korelację pomiędzy stężeniem selenu a liczbą zmian ogniskowych w tarczycy [92]. Zmiany poziomu selenu w surowicy obserwowano także $w$ innych lagodnych i złośliwych chorobach tarczycy [93]. Jak powszechnie wiadomo, choroby tarczycy częściej występują u kobiet niż u mężczyzn [94], jednakże przyczyny tego zjawiska nie zostały dokładnie poznane. Postuluje się wpływ żeńskich hormonów płciowych, ochronne działanie czynników zależnych od obecności chromosomu $\mathrm{Y}$ lub też odmienności w funkcjonowaniu układu immunologicznego u obu płci. Warto także podkreślić, że korzystny wpływ selenu na choroby tarczycy w większości przypadków został wykazany u kobiet, podczas gdy u mężczyzn w wielu innych narządach [83, 95-98].

Dane o prawdziwości hipotezy odnośnie korzystnego wpływu suplementacji selenem na raka tarczycy są raczej skąpe i dotyczą głównie jego postaci brodawkowatej [99-101]. W wielu badaniach na modelach zwierzęcych oraz epidemiologicznych i interwencyjnych stwierdzono korzystny wpływ prawidłowych, a nawet podwyższonych stężeń selenu $\mathrm{w}$ surowicy na inicjację, progresję, a nawet przerzuty różnych rodzajów nowotworów, ale nie raka tarczycy [50, 102]. Związek pomiędzy zaopatrzeniem $\mathrm{w}$ selen i występowaniem raka tarczycy został zweryfikowany w wielu badaniach klinicznych (Tabela I) i w metaanalizie, jednakże nie został jednoznacznie potwierdzony, zwłaszcza w polskiej populacji [103-111]. Dostęp głównie do danych retrospektywnych, relatywnie małe grupy pacjentów i krótki czas obserwacji oraz pojedyncze oznaczenia zaopatrzenia w selen stanowią istotne ograniczenia przeprowadzonych badań. Należy też brać pod uwagę fakt, że niskie stężenie selenu może być nie przyczyną, lecz skutkiem występowania chorób o charakterze ogólnoustrojowym, w tym także nowotworowych, chociażby w efekcie utrzymywania się przewlekłego stanu zapalnego, co może upośledzać produkcję selenoproteiny $\mathrm{P}$ w wątrobie, będącej jak wiadomo odzwierciedleniem zaopatrzeniu ustroju w ten mikroelement [112-115].

\section{Selen w chorobach autoimmunologicznych tarczycy}

Wiadomo, że selen wpływa na proces różnicowania limfocytów T. Jego większa podaż może indukować produkcję regulatorowych limfocytów T, zmniejszać syntezę przeciwciał skierowanych przeciwko antygenom tarczycy i nacieków limfocytarnych [116], podczas gdy jego niedobór może nasilać aktywność limfocytów pomocniczych Th2 [117]. Ponadto, na modelu zwierzęcym przewlekłego autoimmunologicznego zapalenia tarczycy (PAZT) wykazano, że podaż selenu tłumi Th1-zależną odpowiedź immunologiczną, hamując tym samym odpowiedź zapalną i powstawanie zmian destrukcyjnych w GT [118]. Dodatkowo, we krwi zdrowych mężczyzn suplementowanych preparatem selenu stwierdzono zmniejszenie liczby limfocytów NK [119]. Opisane powyżej wyniki sugerują korzystny wpływ selenu na przebieg i występowanie autoimmunologicznych chorób tarczycy $[83,120]$. U kobiet zagrożonych wystąpieniem poporodowego zapalenia tarczycy właściwa podaż wspomnianego mikroelementu może zapobiegać tej jednostce chorobowej, choć dane płynące $\mathrm{z}$ badań klinicznych wymagają jeszcze dodatkowego potwierdzenia [121, 122].

Ponadto, w surowicy pacjentów z chorobą Gravesa i Basedowa oraz niedoczynności $w$ przebiegu PAZT stwierdzano niższe stężenia selenu w surowicy. Jednakże wyniki badań podejmujących temat korelacji pomiędzy stężeniami przeciwciał skierowanych przeciwko TPO (anty-TPO) i TG (anty-TG) oraz receptorowi dla TSH (anty-TSHR) a zaopatrzeniem w selen są, znacznie mniej jednoznaczne [123]. W wielu badaniach interwencyjnych nie wykazano związku między czasem podawania i dawką selenu a zmianami w stężeniach TSH i HT, jednakże większość $\mathrm{z}$ nich nie była prowadzona $\mathrm{w}$ stanach dużego niedoboru selenu [44, 98, 124, 125]. Zatem wyniki tych badań mogą być także spowodowane dobrymi mechanizmami zaopatrzenia w selen tarczycy oraz przedniego płata przysadki, pomimo utrzymującego się deficytu ogólnoustrojowego.

Przeprowadzono również wiele badań prospektywnych, które miały na celu ocenę nasilenia objawów wynikających z rozpoznanej autoimmunologicznej choroby tarczycy, a także jakości życia pacjentów oraz stężeń i produkcji HT. Wyniki metaanaliz tych badań są często rozbieżne i niejednoznaczne. $W$ jednej z metaanaliz [123] autorzy przeanalizowali rezultaty 4 badań klinicznych oceniających wpływ suplementacji selenianem (IV) sodu oraz selenometioniną w dobowej dawce $200 \mu \mathrm{g}$ na różne punkty końcowe u pacjentów z rozpoznanym PAZT. We wszystkich 3 badaniach, gdzie zastosowano selenometioninę stwierdzono znamienne obniżenie stężenia przeciwciał anty-TPO. Wspomniany efekt nie był istotny w populacji, którą suplementowano selenianem, jednakże $\mathrm{w}$ tym badaniu stwierdzono poprawę jakości życia pacjentów [123]. Pomimo korzystnych i zachęcających do suplementacji wyników autorzy opisanego powyżej opracowania statystycznego zalecają ostrożne podejście do tematu, z uwagi na dużą heterogeniczność i relatywnie małą liczebność badanych populacji, różny czas obserwacji (średnio 7,5 miesiąca) oraz wysokie ryzyko stronniczości [123]. Badając wpływ selenu na pacjentów 
Tabela I. Krótka charakterystyka najważniejszych badań klinicznych dot. zwiq̨zku pomiędzy selenem a rakiem tarczycy

\begin{tabular}{|c|c|c|c|c|c|}
\hline Badanie & Grupa badana & $\begin{array}{l}\text { Czas trwania } \\
\text { i typ badania }\end{array}$ & Opis interwencji-grupy & $\begin{array}{l}\text { Najważniejsze } \\
\text { oceniane } \\
\text { parametry }\end{array}$ & Najważniejsze wyniki \\
\hline $\begin{array}{l}\text { Glattre i wsp. } \\
\text { Int J Epidemiol } \\
\text { (1989) [103] }\end{array}$ & $\begin{array}{l}\text { Populacja } 172 \\
\text { pacjentów } \\
\text { (124 kobiety i } 48 \\
\text { mężczyzn) }\end{array}$ & $\begin{array}{l}\text { Badanie } \\
\text { przekrojowe }\end{array}$ & $\begin{array}{l}\text { Grupa kontrolna }(\mathrm{n}=129) \\
\text { Grupa badana z rakiem tarczycy } \\
(\mathrm{n}=43)\end{array}$ & $\begin{array}{l}\text { Różnice w stężeniach } \\
\text { selenu w surowicy } \\
\text { i ich związek } \\
\text { z ryzykiem } \\
\text { wystąpienia raka } \\
\text { tarczycy }\end{array}$ & $\begin{array}{l}\text { Niższe stężenie selenu } \\
\text { u pacjentów z rakiem tarczycy } \\
\text { Ryzyka względne (RR) wystąpienia } \\
\text { raka tarczycy w zależności od } \\
\text { stężenia selenu: } \\
\mathrm{RR}=1 \text { dla } \geq 1,65 \mu \mathrm{mol} / \mathrm{l} \\
\mathrm{RR}=6,1 \text { dla } 1,26-1,64 \mu \mathrm{mol} / \mathrm{l} \\
\mathrm{RR}=7,7 \text { dla } \leq 1,25 \mu \mathrm{mol} / \mathrm{l}\end{array}$ \\
\hline $\begin{array}{l}\text { Kucharzewski } \\
\text { i wsp. Biol } \\
\text { Trace Elem Res } \\
\text { (2002) [104] }\end{array}$ & $\begin{array}{l}\text { Populacja } 87 \text { osób } \\
\text { ( } 85 \text { kobiet } \\
\text { i } 2 \text { mężczyzn) }\end{array}$ & $\begin{array}{l}\text { Badanie } \\
\text { przekrojowe }\end{array}$ & $\begin{array}{l}\text { Pacjenci z łagodnymi chorobami } \\
\text { tarczycy ( } 41 \text { kobiet z wolem } \\
\text { guzkowym, } 18 \text { z chorobą } \\
\text { Gravesa i Basedowa, } \\
7 \text { z przewlekłym zapaleniem } \\
\text { tarczycy) } \\
21 \text { pacjentów z rakiem tarczycy } \\
\text { (19 kobiet i } 2 \text { mężczyzn) }\end{array}$ & $\begin{array}{l}\text { Różnice w stężeniach } \\
\text { selenu w surowicy } \\
\text { oraz tkance tarczycy }\end{array}$ & $\begin{array}{l}\text { Nieznamienne różnice } \\
\text { w stężeniach selenu w surowicy } \\
\text { pomiędzy grupami } \\
\text { Znamiennie niższe stężenie selenu } \\
\text { w tkance tarczycy w grupie } \\
\text { chorych z rakiem }\end{array}$ \\
\hline $\begin{array}{l}\text { Moncayo } \\
\text { i wsp. } \\
\text { BMC Endocr } \\
\text { Disord (2008) } \\
\text { [105] }\end{array}$ & $\begin{array}{l}1401 \text { pacjentów } \\
\text { (1186 dorosłych } \\
\text { i } 215 \text { dzieci) z ch. } \\
\text { łagodnymi oraz } \\
\text { rakiem tarczycy }\end{array}$ & $\begin{array}{l}\text { Badanie } \\
\text { przekrojowe }\end{array}$ & $\begin{array}{l}\text { Grupy dot. analizy selenu: } \\
\text { Kontrola ( } \mathrm{n}=687 \text { ) } \\
\text { Łagodne choroby tarczycy } \\
\text { ( } \mathrm{n}=550 ; 465 \text { dorosłych, } \\
85 \text { dzieci) } \\
\text { Rak tarczycy ( } \mathrm{n}=164 ; 42 \text { z } \\
\text { pęcherzykowym, } \\
73 \text { z brodawkowatym oraz } \\
3 \text { z anaplastycznym rakiem } \\
\text { tarczycy). }\end{array}$ & $\begin{array}{l}\text { Różnice w stężeniach } \\
\text { selenu w surowicy } \\
\text { oraz ocena korelacji } \\
\text { tych stężeń } \\
\text { z innymi mierzalnymi } \\
\text { parametrami }\end{array}$ & $\begin{array}{l}\text { Stężenie selenu było znamiennie } \\
\text { niższe w: } \\
\text { 1. Populacji pacjentów z chorobami } \\
\text { tarczycy w porównaniu z kontrolą } \\
\text { 2. Podgrupach z podostrym } \\
\text { i cichym zapaleniem tarczycy } \\
\text { 3. W grupie pacjentów z rakiem } \\
\text { pęcherzykowym i brodawkowatym } \\
\text { Brak znamiennych korelacji } \\
\text { pomiędzy stężeniem selenu } \\
\text { a wiekiem, płcią, BMI, obrazem } \\
\text { scyntygraficznym oraz USG } \\
\text { tarczycy, stężeniem hormonów } \\
\text { oraz przeciwciał przeciwko } \\
\text { antygenom tarczycy }\end{array}$ \\
\hline $\begin{array}{l}\text { Przybylik- } \\
\text {-Mazurek i wsp. } \\
\text { Biol Trace Elem } \\
\text { Res (2011) } \\
{[106]}\end{array}$ & $\begin{array}{l}\text { Kobiety z } \\
\text { PAZT, rakiem } \\
\text { pęcherzykowym } \\
\text { i brodawkowatym } \\
\text { tarczycy }\end{array}$ & $\begin{array}{l}\text { Badanie } \\
\text { przekrojowe }\end{array}$ & $\begin{array}{l}\text { Kontrola }(\mathrm{n}=20) \\
\text { Pacjenci z PAZT }(\mathrm{n}=17) \\
\text { Pacjenci z rakiem } \\
\text { brodawkowatym }(\mathrm{n}=25) \\
\text { Pacjenci z rakiem } \\
\text { pęcherzykowym }(\mathrm{n}=13)\end{array}$ & $\begin{array}{l}\text { Różnice w stężeniach } \\
\text { mikroelementów } \\
\text { w surowicy, między } \\
\text { innymi selenu } \\
\text { i peroksydazy } \\
\text { glutationu (PG) } 3\end{array}$ & $\begin{array}{l}\text { Brak istotnych różnic w stężeniach } \\
\text { selenu oraz PG3 pomiędzy grupami }\end{array}$ \\
\hline $\begin{array}{l}\text { Jonklaas i wsp. } \\
\text { Thyroid (2013) } \\
\text { [107] }\end{array}$ & $\begin{array}{l}65 \text { pacjentów } \\
\text { zakwalifikowanych } \\
\text { do zabiegu } \\
\text { tyreoidektomii ( } 46 \\
\text { kobiet i } 19 \text { mężczyzn) }\end{array}$ & $\begin{array}{l}\text { Badanie } \\
\text { przekrojowe }\end{array}$ & $\begin{array}{l}\text { Zakwalifikowani do zabiegu } \\
\text { z powodu wola ( } \mathrm{n}=17 \text { ) } \\
\text { Zakwalifikowani do zabiegu } \\
\text { z powodu raka tarczycy ( } \mathrm{n}= \\
\text { 48; w rozpoznaniu hist.-pat.: } 35 \\
\text { przyp. raka brodawkowatego } \\
\text { i } 9 \text { jego wariantu pęcherzykowego } \\
\text { oraz } 4 \text { raka pęcherzykowego) }\end{array}$ & $\begin{array}{l}\text { Ocena porównawcza } \\
\text { przedoperacyjnych } \\
\text { stężeń selenu } \\
\text { i } 25(0 H) \text { wit. D3 } \\
\text { w surowicy oraz ich } \\
\text { korelacja ze stopniem } \\
\text { zaawansowania } \\
\text { choroby }\end{array}$ & $\begin{array}{l}\text { 1. Nieznamienne różnice } \\
\text { w stężeniach pomiędzy grupami } \\
\text { 2. Odwrotna, znamienna korelacja } \\
\text { pomiędzy stężeniem selenu } \\
\text { a stopniem zaawansowania } \\
\text { nowotworu }\end{array}$ \\
\hline $\begin{array}{l}\text { O'Grady i wsp. } \\
\text { PLoS One } \\
\text { (2014) [108] }\end{array}$ & $\begin{array}{l}566398 \text { pacjentów } \\
\text { zakwalifikowanych do } \\
\text { badania NIH-AARP } \\
\text { (National Institute } \\
\text { of Health-American } \\
\text { Association of Retired } \\
\text { Persons) }\end{array}$ & $\begin{array}{l}\text { Badanie } \\
\text { prospektywne } \\
\text { rozpoczęte w } \\
1995 \text { roku }\end{array}$ & $\begin{array}{l}\text { Wśród przebadanej populacji } \\
\text { zidentyfikowano } 592 \text { przypadki } \\
\text { raka ( } 257 \text { mężczyzn i } 335 \text { kobiet): } \\
406 \text { rozpoznań raka } \\
\text { brodawkowatego } \\
\text { (164 przypadki u mężczyzn } \\
242 \text { u kobiet) } \\
113 \text { rozpoznań raka } \\
\text { pęcherzykowego } \\
\text { (57 u mężczyzn i } 56 \text { u kobiet) }\end{array}$ & $\begin{array}{l}\text { Ocena korelacji } \\
\text { pomiędzy spożyciem } \\
\text { selenu a także innych } \\
\text { mikroelementów oraz } \\
\text { witamin } \\
\text { a zapadalnością na } \\
\text { raka tarczycy }\end{array}$ & $\begin{array}{l}\text { Nie stwierdzono istotnej zależności } \\
\text { pomiędzy kwintylami niższego } \\
\text { spożycia selenu a zwiększoną } \\
\text { zapadalnością na raka tarczycy }\end{array}$ \\
\hline
\end{tabular}


Tabela I (cd.). Krótka charakterystyka najważniejszych badań klinicznych dot. zwiq̨zku pomiędzy selenem a rakiem tarczycy

\begin{tabular}{|c|c|c|}
\hline $\begin{array}{l}\text { Shen i wsp. } \\
\text { Biol Trace Elem } \\
\text { Res } \\
(2015)[109]\end{array}$ & $\begin{array}{l}\text { Metaanaliza danych Metaanaliza } \\
\text { z } 8 \text { badań klinicznych } \\
\text { ( } 4 \text { dot. selenu). } \\
\text { Łączna liczba } \\
\text { pacjentów } 1291 \\
\text { osób }\end{array}$ & $\begin{array}{l}\text { Metaanaliza danych } \\
\text { z badań przeprowadzonych } \\
\text { w populacjach: norweskiej, } \\
\text { austriackiej i polskiej }\end{array}$ \\
\hline
\end{tabular}

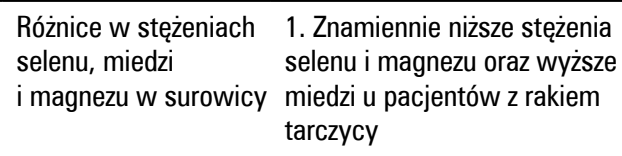

2. Analiza w podgrupach potwierdziła obecność niższych stężeń selenu w populacji norweskiej i austriackiej, lecz nie w populacji polskiej

\begin{tabular}{|c|c|c|c|c|c|}
\hline $\begin{array}{l}\text { Baltaci i wsp. } \\
\text { Biol Trace Elem } \\
\text { Res (2016) } \\
{[110]}\end{array}$ & $\begin{array}{l}50 \text { pacjentów } \\
\text { płci obojga ( } 30 \\
\text { osób z hist.-pat. } \\
\text { rozpoznaniem raka } \\
\text { brodawkowatego } \\
\text { tarczycy) }\end{array}$ & $\begin{array}{l}\text { Badanie } \\
\text { przekrojowe }\end{array}$ & $\begin{array}{l}\text { Kobiety z pooperacyjnym } \\
\text { rozpoznaniem raka tarczycy } \\
\text { (n=15) } \\
\text { Mężczyźni z pooperacyjnym } \\
\text { rozpoznaniem raka tarczycy } \\
\text { (n }=15 \text { ) } \\
\text { Kobiety ze zmianami łagodnymi } \\
\text { w badaniu hist.-pat } \\
\text { Mężczyźni ze zmianami } \\
\text { łagodnymi w badaniu hist.-pat }\end{array}$ & $\begin{array}{l}\text { Porównanie stężeń } \\
\text { selenu i cynku w } \\
\text { surowicy przed, tuż } \\
\text { po oraz po } 15 \text { dniach } \\
\text { od zabiegu oraz w } \\
\text { tkance tarczycowej po } \\
\text { zabiegu }\end{array}$ & $\begin{array}{l}\text { 1.Przed i pooperacyjne stężenia } \\
\text { cynku i selenu w grupach } 1 \\
\text { i } 2 \text { były znamiennie niższe } \\
\text { w surowicy, a wyższe w } \\
\text { tkance tarczycy niż w grupach } \\
\text { kontrolnych } \\
2.15 \text { dni po zabiegu nie było } \\
\text { istotnych różnić między grupami }\end{array}$ \\
\hline $\begin{array}{l}\text { Chung i wsp. } \\
\text { Biol Trace } \\
\text { Elem Res } \\
\text { (2016) [111] }\end{array}$ & $\begin{array}{l}92 \text { Koreanki } \\
\text { poddane zabiegowi } \\
\text { tyreoidektomii }\end{array}$ & $\begin{array}{l}\text { Badanie } \\
\text { przekrojowe }\end{array}$ & $\begin{array}{l}92 \text { Koreanki poddane } \\
\text { zabiegowi tyreoidektomii } \\
\text { i z hist.-pat. rozpoznaniem raka } \\
\text { brodawkowatego tarczycy }\end{array}$ & $\begin{array}{l}\text { Ocena stężeń/ } \\
\text { /zawartości kadmu, } \\
\text { selenu } \\
\text { i cynku w materiale } \\
\text { pooperacyjnym } \\
\text { oraz ocena ich } \\
\text { korelacji ze stopniem } \\
\text { zaawansowania } \\
\text { nowotworu tarczycy }\end{array}$ & $\begin{array}{l}\text { Stężenia kadmu, selenu i cynku } \\
\text { były znamiennie wyższe } \\
\text { w stadiach III i IV wg TNM }\end{array}$ \\
\hline
\end{tabular}

PAZT — przewlekłe autoimmunologiczne zapalenie tarczycy

z chorobą Hashimoto, autorzy kolejnej metaanalizy [120] także stwierdzili znamienne obniżenie stężeń przeciwciał anty-TPO oraz poprawę jakości życia już po 3 miesiącach suplementacji. Ponadto autorzy zaobserwowali zależność pomiędzy siłą odpowiedzi na suplementację a stężeniami początkowymi przeciwciał anty-TPO. W innej metaanalizie uwzględniono 9 badań oraz dane pochodzące od 787 pacjentów. Wszyscy pacjenci otrzymywali $200 \mu \mathrm{g}$ selenianu lub selenometioniny oraz ewentualnie dodatkowo L-tyroksynę (w 4 badaniach) oraz metimazol (w 1 badaniu). W zdecydowanej większości byli to chorzy z PAZT, a w jednym badaniu analizowano efektywność terapii u pacjentów z rozlanym wolem toksycznym. 6-miesięczna suplementacja spowodowała znamienne obniżenie stężeń przeciwciał anty-TPO. Z kolei, wyniki uzyskane po 12 miesiącach terapii wykazały istotny spadek poziomów przeciwciał anty-TG oraz również anty-TPO. Ponadto, $w$ oparciu o dane płynące $z$ dwóch badań potwierdzono korzystny wpływ suplementacji wspomnianym mikroelementem na nastrój pacjentów [126]. Krótką charakterystykę najważniejszych prospektywnych badań klinicznych [98, 122, 127-144] efektywności suplementacji selenu w łagodnych chorobach tarczycy, w szczególności tych o podłożu autoimmunologicznym umieszczono w Tabeli II.

\section{Rola selenu w orbitopatii tarczycowej}

Marcocci i wsp. [145] badali skuteczność suplementacji selenem w populacji 159 pacjentów z łagodną orbitopatią tarczycową w przebiegu choroby Gravesa i Basedowa. Populację podzielono na 3 grupy: pierwsza — kontrolna otrzymywała placebo, druga $600 \mathrm{mg}$ pentoksyfiliny dwa razy dziennie, a trzecia $100 \mu$ g selenianu (IV) sodu dwa razy dziennie. Po 6 miesiącach terapii selenianem badacze zaobserwowali znamienną poprawę jakości życia, mniejsze nasilenie zmian ocznych i zahamowanie postępu orbitopatii do cięższych form. Nasilenie aktywności zmian ocznych, ocenianych skalą CAS (ang. Clinical Activity Score), zmniejszyło się we wszystkich grupach, ale było ono znamiennie niższe $\mathrm{w}$ grupie otrzymującej selen. Uzyskane po 12 miesiącach wyniki już po odstawieniu selenu, były analogiczne do uzyskanych wcześniej [145]. Zaprezentowane powyżej rezultaty przyczyniły się do uwzględnienia suplementacji selenem w wydanych w 2016 roku rekomendacjach Europejskiego Towarzystwa Tyreologicznego, zgodnie $\mathrm{z}$ którymi $\mathrm{w}$ łagodnych formach krótko trwającej orbitopatii tarczycowej zaleca się stosowanie selenianu sodu (100 $\mu \mathrm{g} 2 \times$ dziennie) przez 6 miesięcy [146], choć zachęcano do jego stosowania 
Tabela II. Krótka charakterystyka najważniejszych badań klinicznych dot. związku pomiędzy selenem a łagodnymi chorobami tarczycy

\begin{tabular}{|c|c|c|c|c|c|}
\hline Badanie & Grupa badana & $\begin{array}{l}\text { Czas } \\
\text { trwania i } \\
\text { typ badania }\end{array}$ & $\begin{array}{l}\text { Opis interwencji- } \\
\text { grupy }\end{array}$ & $\begin{array}{l}\text { Najważniejsze } \\
\text { oceniane } \\
\text { parametry }\end{array}$ & Najważniejsze wyniki \\
\hline $\begin{array}{l}\text { Gartner i wsp. } \\
\text { JCEM (2002) } \\
\text { [127] }\end{array}$ & $\begin{array}{l}70 \text { pacjentek } \\
\text { z PAZT }\end{array}$ & $\begin{array}{l}3 \text { miesiące; } \\
\text { RBK }\end{array}$ & $\begin{array}{l}\mathrm{L}-\mathrm{T} 4+200 \mu \mathrm{g} / \text { dobę } \\
\text { selenianu sodu ( } \mathrm{n}=36 \text { ) } \\
\mathrm{L}-\mathrm{T} 4+\text { placebo } \\
\text { (n=34) } \\
\text { Średnie początkowe } \\
\text { stężenie selenu } \\
\text { w surowicy: } \\
0,87-0,91 \mu \mathrm{mol} / \mathrm{l}\end{array}$ & $\begin{array}{l}\text { Stężenia TSH, fT3, fT4 } \\
\text { Stężenia aTPO, aTG } \\
\text { Obraz USG tarczycy } \\
\text { Dobrostan pacjentów }\end{array}$ & $\begin{array}{l}\text { 1. Znamienny spadek aTPO w grupie badanej } \\
\text { i brak istotnej różnicy w grupie placeb } \\
\text { 2. Brak istotnej różnicy pomiędzy stężeniami aTG w gru- } \\
\text { pie badanej i znamienny spadek w grupie kontrolnej } \\
\text { 3. U znamiennie większej liczby pacjentek z grupy } \\
\text { badanej doszło do normalizacji stężeń aTPO i aTG } \\
\text { oraz echogeniczności tarczycy, a także do poprawy } \\
\text { samopoczucia }\end{array}$ \\
\hline $\begin{array}{l}\text { Gartner i wsp. } \\
\text { Biofactors } \\
\text { (2003) [128] }\end{array}$ & $\begin{array}{l}47 \text { pacjentek z } \\
\text { PAZT } \\
\text { z poprzedniego } \\
\text { badania } \\
\text { (JCEM 2002) }\end{array}$ & $\begin{array}{l}6 \text { miesięcy; } \\
\text { NRBK }\end{array}$ & $\begin{array}{l}\text { Grupa poprzednio } \\
\text { otrzymująca selen } \rightarrow \\
\text { kontynuacja (Se-Se) } \\
(\mathrm{n}=13) \\
\text { Grupa poprzednio } \\
\text { otrzymująca selen } \rightarrow \\
\text { placebo (Se-0) }(\mathrm{n}=9 \text { ) } \\
\text { Grupa placebo } \rightarrow 200 \\
\mu \mathrm{g} / \text { dobę selenianu sodu } \\
(0-\mathrm{Se})(\mathrm{n}=14) \\
\text { Grupa placebo } \rightarrow \\
\text { placebo }(0-0)(\mathrm{n}=11)\end{array}$ & $\begin{array}{l}\text { Stężenia TSH, fT3, fT4 } \\
\text { Stężenia aTP0, aTG } \\
\text { Obraz USG tarczycy }\end{array}$ & $\begin{array}{l}\text { 1. W grupie } 1 \text { i } 3 \text { doszło do znamiennego obniżenia } \\
\text { aTPO } \\
\text { 2. W grupie } 2 \text { stężenie aTPO wzrosło a w grupie } 4 \\
\text { nie uległo istotnej zmianie } \\
\text { 3. Stężenia aTG nie uległy istotnej zmianie } \\
\text { 4. U trzech pacjentów z grupy } 4 \text { i dwóch z grupy } \\
2 \text { doszło do wzrostu TSH powyżej normy pomimo } \\
\text { kontynuacji L-tyroksyny } \\
\text { 5. U trzech pacjentów z grupy } 1 \text { i dwóch z grupy } 3 \\
\text { doszło do obniżenia przeciwciał aTPO i aTG < } 40 \text { IU/ } \\
\text { /ml oraz normalizacji echogeniczności tarczycy }\end{array}$ \\
\hline $\begin{array}{l}\text { Duntas } \\
\text { i wsp. Eur J } \\
\text { Endocrinol } \\
\text { (2003) [129] }\end{array}$ & $\begin{array}{l}65 \text { pacjentek } \\
\text { z PAZT }\end{array}$ & $\begin{array}{l}6 \text { miesięcy; } \\
\text { RBK }\end{array}$ & $\begin{array}{l}65 \text { pacjentów (56 } \\
\text { kobiet i } 9 \text { mężczyzn) } \\
\text { z aTP0 > } 100 \\
\text { U/I z subkliniczną } \\
\text { niedoczynnością } \\
\text { tarczycy } \\
\text { L-T4 + } 200 \mu \mathrm{g} \\
\text { selenometioniny } \\
\text { (n }=34 \text { ) } \\
\text { L-T4 + placebo } \\
\text { (n }=31 \text { ) } \\
\text { Średnie początkowe } \\
\text { stężenie selenu } \\
\text { w surowicy }-75 \mu \mathrm{g} / \mathrm{L}\end{array}$ & $\begin{array}{l}\text { Stężenia TSH, fT3, fT4 } \\
\text { Stężenia aTP0, aTG } \\
\text { Stężenie selenu } \\
\text { w surowicy }\end{array}$ & $\begin{array}{l}\text { 1. Stężenia przeciwciał aTPO uległy znamiennemu } \\
\text { obniżeniu w obu grupach } \\
\text { 2. Różnice między grupami nie były istotne } \\
\text { 3. Nie stwierdzono zmian w stężeniach aTG } \\
\text { 4. Stężenia TSH, fT3,fT4 w normie i bez zmian }\end{array}$ \\
\hline $\begin{array}{l}\text { Turker i wsp. } \\
\text { J Endocrinol } \\
(2006)[130]\end{array}$ & $\begin{array}{l}88 \text { pacjentek } \\
\text { z PAZT }\end{array}$ & $\begin{array}{l}9 \text { miesięcy; } \\
\text { RBK }\end{array}$ & $\begin{array}{l}\mathrm{L}-\mathrm{T} 4+200 \mu \mathrm{g} \\
\text { selenometioniny } \\
\text { (n=48). Redukcja } \\
\text { dawki do } 100 \mu \mathrm{g} \text { po } \\
3 \text { miesiącach u części } \\
\text { pacjentów } \\
\text { Placebo } \\
\text { Średnie początkowe } \\
\text { stężenie selenu } \\
\text { w surownicy - } \\
\text { niezmierzone }\end{array}$ & $\begin{array}{l}\text { Stężenia TSH, fT3, fT4 } \\
\text { Stężenia aTP0, aTG }\end{array}$ & $\begin{array}{l}\text { 1. Obniżenie przeciwciał pod wpływem } 200 \mu \mathrm{g} / \\
\text { /dobę selenu } \\
\text { 2. Dawka } 200 \mu \mathrm{g} \text { wydaje się mieć przewagę nad } \\
100 \mu \mathrm{g} \\
\text { 3. Stężenia TSH, fT3,fT4 w normie i bez zmian }\end{array}$ \\
\hline $\begin{array}{l}\text { Mazokopakis i } \\
\text { wsp. Thyroid } \\
\text { (2007) [131] }\end{array}$ & $\begin{array}{l}80 \text { pacjentek } \\
\text { z PAZT }\end{array}$ & $\begin{array}{l}12 \text { miesięcy; } \\
\text { NRBK }\end{array}$ & $\begin{array}{l}\text { Przez } 6 \text { miesięcy } 200 \\
\mu \mathrm{g} \text { selenometioniny, } \\
\text { potem przez kolejnych } \\
6 \text { miesięcy: } \\
\text { Kontynuacja } \\
\text { suplementacji }(\mathrm{n}=40 \text { ) } \\
\text { Placebo ( } \mathrm{n}=40 \text { ) } \\
\text { Średnie początkowe } \\
\text { stężenie selenu } \\
\text { w surowicy - brak } \\
\text { danych }\end{array}$ & $\begin{array}{l}\text { Stężenia TSH, fT3, fT4 } \\
\text { Stężenia aTP0, aTG }\end{array}$ & $\begin{array}{l}\text { 1. Znamienny spadek aTPO w pierwszej } \\
\text { fazie i dalszy spadek w grupie kontynuującej } \\
\text { suplementację (grupa 1) } \\
\text { 2. Wzrost stężenia aTPO w grupie otrzymującej } \\
\text { placebo } \\
\text { 3. Brak zmian w stężeniu aTG } \\
\text { 4. Stężenia TSH, fT3,fT4 w normie i bez zmian }\end{array}$ \\
\hline
\end{tabular}


Tabela II (cd.). Krótka charakterystyka najważniejszych badań klinicznych dot. związku pomiędzy selenem a tagodnymi chorobami tarczycy

\begin{tabular}{|c|c|c|c|c|c|}
\hline $\begin{array}{l}\text { Negro i wsp. } \\
\text { JCEM (2007) } \\
{[122]}\end{array}$ & $\begin{array}{l}\text { Ciężarne } \\
\text { pacjentki } \\
\text { w eutyreozie: } \\
169 \text { z wysokimi } \\
\text { stężeniami } \\
\text { aTPO oraz } \\
85 \text { z niskimi } \\
\text { stężeniami } \\
\text { aTPO }\end{array}$ & $\begin{array}{l}\text { Od } 12 \\
\text { tygodnia } \\
\text { ciąży do } 12 \\
\text { miesiąca po } \\
\text { porodzie; } \\
\text { RBK }\end{array}$ & $\begin{array}{l}200 \mu \mathrm{g} \\
\text { selenometioniny } \\
\text { (n=85) } \\
\text { Placebo (n=84) } \\
\text { Grupa kontrolna aTP0 } \\
(-)(\mathrm{n}=85) \\
\text { Średnie początkowe } \\
\text { stężenie selenu } \\
\text { w surowicy - } \\
78,8 \mu \mathrm{g} / \mathrm{l}\end{array}$ & $\begin{array}{l}\text { Stężenia TSH, fT4, } \\
\text { aTPO } \\
\text { Stężenie selenu } \\
\text { w surowicy } \\
\text { Obraz USG tarczycy }\end{array}$ & $\begin{array}{l}\text { 1. Mniejsza częstość występowania } \\
\text { poporodowego zapalenia i trwałej niedoczynności } \\
\text { tarczycy w grupie otrzymującej selen } \\
\text { Bez istotnych różnic w obrazie USG w grupie } \\
\text { otrzymującej selen oraz istotne pogorszenie obrazu } \\
\text { w grupie kontrolnej pod koniec okresu obserwacji, } \\
\text { w porównaniu z początkiem ciąży }\end{array}$ \\
\hline $\begin{array}{l}\text { Karanikas i } \\
\text { wsp. Thyroid } \\
\text { (2008) [132] }\end{array}$ & $\begin{array}{l}36 \text { pacjentek } \\
\text { z PAZT }\end{array}$ & $\begin{array}{l}3 \text { miesiące; } \\
\text { RBK }\end{array}$ & $\begin{array}{l}\mathrm{L}-\mathrm{T} 4+200 \mu \mathrm{g} \\
\text { selenianu sodu ( } \mathrm{n}=18 \text { ) } \\
\text { L-T4 + placebo ( } \mathrm{n}=18 \text { ) } \\
\text { Średnie początkowe } \\
\text { stężenie selenu } \\
\text { w surowicy - } 75 \mu \mathrm{g} / \mathrm{l}\end{array}$ & $\begin{array}{l}\text { Stężenia Hormonów } \\
\text { tarczycy i aTPO } \\
\text { Dobrostan pacjentów } \\
\text { Cytokiny limfocytarne } \\
\text { Stężenie selenu } \\
\text { w surowicy }\end{array}$ & $\begin{array}{l}\text { 1. Brak istotnych różnic pomiędzy grupami } \\
\text { w zakresie wyników badań laboratoryjnych } \\
\text { 2. Poprawa samopoczucia częściej zgłaszana } \\
\text { przez pacjentów z grupy otrzymującej selen. TSH, } \\
\text { fT3, fT4 w normie i bez zmian }\end{array}$ \\
\hline $\begin{array}{l}\text { Combs i wsp. } \\
\text { Am J Clin } \\
\text { Nutr (2009) } \\
{[98]}\end{array}$ & $\begin{array}{l}28 \text { zdrowych } \\
\text { osób (13 } \\
\text { mężczyzn) }\end{array}$ & $\begin{array}{l}28 \text { miesięcy; } \\
\text { NRBK }\end{array}$ & $\begin{array}{l}\text { Wszyscy pacjenci } \\
\text { otrzymywali } 200 \mu \mathrm{g} \\
\text { selenometioniny/dobę } \\
\text { przez } 28 \text { miesięcy } \\
\text { Średnie początkowe } \\
\text { stężenie selenu } \\
\text { w surowicy - } \\
1,64 \mu \mathrm{mol} / \mathrm{l} \text { dla kobiet i } \\
1,78 \mu \mathrm{mol} / \mathrm{l} \text { dla mężczyzn }\end{array}$ & $\begin{array}{l}\text { Stężenia TSH, T3, T4 } \\
\text { Stężenie selenu } \\
\text { w surowicy }\end{array}$ & $\begin{array}{l}5 \% \text {, istotny wzrost stężenia T3/rok, bez } \\
\text { towarzyszących zmian TSH i T4 }\end{array}$ \\
\hline $\begin{array}{l}\text { Bonfig i wsp. } \\
\text { Scientific } \\
\text { World Journal } \\
\text { (2010) [133] }\end{array}$ & $\begin{array}{l}49 \text { dzieci } \\
\text { w średnim } \\
\text { wieku 12,2 } \\
\pm 2,2 \text { lat (33 } \\
\text { dziewczynki), } \\
\text { ze świeżo } \\
\text { rozpoznanym } \\
\text { PAZT i } \\
\text { niedoczynnością } \\
\text { tarczycy }\end{array}$ & $\begin{array}{l}12 \text { miesięcy; } \\
\text { RBK }\end{array}$ & $\begin{array}{l}\text { L-T4 (14 kobiet } \\
\text { i } 4 \text { mężczyzn) } \\
\text { L-T4+ } 100 \mu \mathrm{g} / \text { dobę } \\
\text { selenianu sodu } \\
\text { (9 kobiet i } 4 \text { mężczyzn) } \\
\text { L-T4+ } 200 \mu \mathrm{g} / \text { dobę } \\
\text { selenianu sodu } \\
\text { (10 kobiet i } 8 \text { mężczyzn) } \\
\text { Średnie początkowe } \\
\text { stężenie selenu } \\
\text { w surowicy - brak } \\
\text { danych }\end{array}$ & $\begin{array}{l}\text { Stężenia TSH, fT3, fT4 } \\
\text { Stężenia aTPO, aTG }\end{array}$ & $\begin{array}{l}\text { 1. Stężenia aTPO były porównywalne we } \\
\text { wszystkich grupach na początku badania i po } 12 \\
\text { miesiącach terapii } \\
\text { 2. Stężenia przeciwciał aTG uległy znamiennemu } \\
\text { zmniejszeniu w grupie } 1 \text { i } 3 \text { po } 12 \text { miesiącach }\end{array}$ \\
\hline $\begin{array}{l}\text { Nacamulli } \\
\text { i wsp. Clin } \\
\text { Endocrinol } \\
\text { (0xf) (2010) } \\
{[134]}\end{array}$ & $\begin{array}{l}76 \text { pacjentów } \\
\text { (w tym } 65 \\
\text { kobiet) z PAZT, } \\
\text { w eutyreozie lub } \\
\text { z subkliniczną } \\
\text { niedoczynnością } \\
\text { tarczycy }\end{array}$ & $\begin{array}{l}12 \text { miesięcy; } \\
\text { RBK }\end{array}$ & $\begin{array}{l}\text { Placebo ( } 25 \text { kobiet } \\
\text { i } 5 \text { mężczyzn) } \\
80 \mu \mathrm{g} \text { selenianu sodu } \\
\text { przez } 6 \text { miesięcy } \\
\text { ( } 40 \text { kobiet i } 6 \text { mężczyzn) } \\
\text { Średnie początkowe } \\
\text { stężenie selenu } \\
\text { w surowicy - brak } \\
\text { danych }\end{array}$ & $\begin{array}{l}\text { Stężenia TSH,fT4 } \\
\text { Stężenia aTPO, aTG } \\
\text { Obraz USG tarczycy } \\
\text { (echogeniczność) }\end{array}$ & $\begin{array}{l}\text { 1. Bez zmian stężeń TSH, fT4 w grupach } \\
\text { i pomiędzy nimi } \\
\text { 2. Znamienny spadek aTPO i aTG w grupie } 2 \text { po } 12 \\
\text { miesiącach } \\
\text { 3. Istotny spadek echogeniczności w obu grupach } \\
\text { po } 6 \text { miesiącach i dalszy jej spadek po } 12 \\
\text { miesiącach w grupie kontrolnej }\end{array}$ \\
\hline $\begin{array}{l}\text { Krysiak i } \\
\text { Okopien JCEM } \\
\text { (2011) [135] }\end{array}$ & $\begin{array}{l}170 \text { kobiet } \\
\text { w eutyreozie } \\
\text { z PAZT oraz } 41 \\
\text { zdrowych osób }\end{array}$ & $\begin{array}{l}6 \text { miesięcy; } \\
\text { RBK }\end{array}$ & $\begin{array}{l}\text { Pacjentki ze świeżo } \\
\text { rozpoznaną i } \\
\text { nieleczonym PAZT: } \\
\text { L-T4 (42) } \\
200 \mu \mathrm{g} \text { selenometioniny } \\
\text { (43) } \\
\text { L-T4 + } 200 \mu \mathrm{g} \\
\text { selenometioniny (43) } \\
\text { Placebo (42) } \\
\text { Średnie początkowe } \\
\text { stężenie selenu } \\
\text { w surowicy - } \\
\text { niezmierzone (57,5 } \mu \mathrm{g} / \mathrm{l} \\
\text { w tym regionie Polski) }\end{array}$ & $\begin{array}{l}\text { Stężenia aTPO } \\
\text { Stężenia cytokin } \\
\text { limfocytarnych } \\
\text { i monocytarnych } \\
\text { Stężenia parametrów } \\
\text { ostrej fazy }\end{array}$ & $\begin{array}{l}\text { W grupie otrzymującej terapię kombinowaną } \\
\text { odnotowano największy spadek stężeń aTPO, } \\
\text { hsCRP oraz wydzielanych cytokin }\end{array}$ \\
\hline
\end{tabular}


Tabela II (cd.). Krótka charakterystyka najważniejszych badań klinicznych dot. związku pomiędzy selenem a łagodnymi chorobami tarczycy

\begin{tabular}{|c|c|c|c|c|c|}
\hline $\begin{array}{l}\text { Onal i wsp. } \\
\text { J Pediatr } \\
\text { Endocrinol } \\
\text { Metab (2012) } \\
\text { [136] }\end{array}$ & $\begin{array}{l}23 \text { dzieci } \\
\text { w wieku } \\
12,3 \pm 2,4 \\
\text { lat ze świeżo } \\
\text { rozpoznanym } \\
\text { PAZT i w stanie } \\
\text { eutyreozy } \\
\text { (16 dziewczynek } \\
\text { i } 7 \text { chłopców) }\end{array}$ & $\begin{array}{l}3 \text { miesiące; } \\
\text { NRBK }\end{array}$ & $\begin{array}{l}\text { Wszyscy uczestnicy } \\
\text { otrzymywali } 50 \mu \mathrm{g} \\
\text { selenometioniny } \\
\text { dziennie przez } \\
3 \text { miesiące } \\
\text { Średnie początkowe } \\
\text { stężenie selenu } \\
\text { w surowicy — brak } \\
\text { dostępu do danych }\end{array}$ & $\begin{array}{l}\text { Stężenia TSH, fT3, fT4 } \\
\text { Stężenia aTP0, aTG } \\
\text { Obraz USG tarczycy } \\
\text { Stężenie selenu } \\
\text { w surowicy }\end{array}$ & $\begin{array}{l}\text { 1. Stężnia przeciwciał aTPO i aTG oraz } \\
\text { echogeniczność tarczycy nie uległy zmianie } \\
\text { 2. U 35\% pacjentów doszło do zmniejszenia } \\
\text { objętości tarczycy o } \geq 30 \%\end{array}$ \\
\hline $\begin{array}{l}\text { Anastasilakis i } \\
\text { wsp. Int J Clin } \\
\text { Pract (2012) } \\
\text { [137] }\end{array}$ & $\begin{array}{l}86 \text { pacjentów z } \\
\text { PAZT (w tym } 33 \\
\text { mężczyzn) }\end{array}$ & $\begin{array}{l}6 \text { miesięcy } \\
\text { badanie } \\
\text { quasi-RBK }\end{array}$ & $\begin{array}{l}200 \mu \mathrm{g} \\
\text { selenometioniny } \\
\text { przez } 3 \text { miesiące } \\
(\mathrm{n}=15) \\
200 \mu \mathrm{g} \\
\text { selenometioniny przez } \\
6 \text { miesięcy ( } \mathrm{n}=46) \\
\text { Placebo ( } \mathrm{n}=25) \\
\text { Średnie początkowe } \\
\text { stężenie selenu } \\
\text { w surowicy - } \\
83 \mu \mathrm{g} / \mathrm{l}\end{array}$ & $\begin{array}{l}\text { Stężenia TSH, fT3, fT4 } \\
\text { Stężenia aTPO, aTG } \\
\text { Stężenie selenu } \\
\text { w surowicy } \\
\text { Obraz USG tarczycy } \\
\text { Liczba limfocytów } \\
\text { w rozmazie z biopsji } \\
\text { cienkoigłowej } \\
\text { tarczycy (podgrupa } \\
18 \text { pacjentów) }\end{array}$ & $\begin{array}{l}\text { 1. Brak istotnych zmian w stężeniach aTPO } \\
\text { oraz liczbie limfocytów z biopsji w grupach } \\
\text { przyjmujących selen } \\
\text { 2. Znamienny spadek stężeń aTG po } 3 \text { i } 6 \\
\text { miesiącach w grupach otrzymujących selen } \\
\text { 3. Stężenia TSH, fT3 i fT4 nie uległy zmianie }\end{array}$ \\
\hline $\begin{array}{l}\text { Deng i wsp. } \\
\text { Chinese Gen } \\
\text { Practice } \\
\text { (2013) [138] }\end{array}$ & $\begin{array}{l}94 \text { pacjentów } \\
\text { z PAZT } \\
\text { (81 kobiet } \\
\text { i } 13 \text { mężczyzn) }\end{array}$ & $\begin{array}{l}6 \text { miesięcy; } \\
\text { RBK }\end{array}$ & $\begin{array}{l}200 \mu \mathrm{g} \text { selenu ( } \mathrm{n}=48 \\
\text { w tym } 7 \text { mężczyzn) } \\
\text { Placebo ( } \mathrm{n}=46 ; \\
\text { w tym } 6 \text { mężczyzn) } \\
\text { Średnie początkowe } \\
\text { stężenie selenu } \\
\text { w surowicy - brak } \\
\text { danych }\end{array}$ & $\begin{array}{l}\text { Stężenia TSH, fT3, fT4 } \\
\text { Stężenia aTPO, aTG } \\
\text { Obraz USG tarczycy }\end{array}$ & $\begin{array}{l}\text { W porównaniu z grupą kontrolną: } \\
\text { obniżenie stężenia przeciwciał, } \\
\text { zmniejszenie rozmiarów wola i zmian ogniskowych }\end{array}$ \\
\hline $\begin{array}{l}\text { Zhang i wsp. } \\
\text { Medical Innov. } \\
\text { of China } \\
\text { (2013) [139] }\end{array}$ & $\begin{array}{l}66 \text { pacjentów } \\
\text { z PAZT } \\
\text { ( } 61 \text { kobiet } \\
\text { i } 5 \text { mężczyzn) }\end{array}$ & $\begin{array}{l}3 \text { miesiące; } \\
\text { RBK }\end{array}$ & $\begin{array}{l}\text { L-T4 + } 200 \mu \mathrm{g} \text { selenu } \\
\text { z drożdży ( } \mathrm{n}=46 ; \\
\text { w tym } 4 \text { mężczyzn) } \\
\text { L-T4 + placebo } \\
\text { (n = 20; w tym } \\
1 \text { mężczyzna) } \\
\text { Średnie początkowe } \\
\text { stężenie selenu } \\
\text { w surowicy - brak } \\
\text { danych }\end{array}$ & $\begin{array}{l}\text { Stężenia TSH, fT3, fT4 } \\
\text { Stężenia aTPO, aTG }\end{array}$ & $\begin{array}{l}\text { 1. Znamienny spadek stężeń aTPO w obu grupach, } \\
\text { bez różnic pomiędzy nimi } \\
\text { 2. Brak zmian stężeń aTG }\end{array}$ \\
\hline $\begin{array}{l}\text { Eskes i } \\
\text { wsp. Clin } \\
\text { Endocrinol } \\
\text { (0xf) (2014) } \\
{[140]}\end{array}$ & $\begin{array}{l}61 \text { kobiet z } \\
\text { PAZT w stanie } \\
\text { eutyreozy } \\
\text { nieleczonych } \\
\text { L-T4 }\end{array}$ & $\begin{array}{l}9 \text { miesięcy; } \\
\text { RBK }\end{array}$ & $\begin{array}{l}200 \mu \mathrm{g} \text { selenianu sodu } \\
\text { przez } 6 \text { miesięcy } \\
\text { ( } \mathrm{n}=30 \text { ) } \\
\text { Placebo przez } \\
6 \text { miesięcy }(\mathrm{n}=31 \text { ) } \\
\text { Średnie początkowe } \\
\text { stężenie selenu } \\
\text { w surowicy - } \\
72,9 \text { i } 74,7 \mu \mathrm{g} / \mathrm{l}\end{array}$ & $\begin{array}{l}\text { Stężenia TSH, fT4, } \\
\text { aTP0 } \\
\text { Stężenie selenu } \\
\text { i SPP1 w surowicy } \\
\text { Jakość życia }\end{array}$ & $\begin{array}{l}\text { 1. Brak istotnych zmian TSH, fT4, aTPO w grupach } \\
\text { oraz różnic pomiędzy nimi } \\
\text { 2. Brak różnic w jakości życia pomiędzy grupami }\end{array}$ \\
\hline $\begin{array}{l}\text { Calissendorff } \\
\text { i wsp. Eur } \\
\text { Thyroid J } \\
\text { (2015) [141] }\end{array}$ & $\begin{array}{l}38 \text { pacjentów } \\
\text { z chorobą } \\
\text { Gravesa i } \\
\text { Basedowa } \\
\text { (31 kobiet) }\end{array}$ & $\begin{array}{l}9 \text { miesięcy; } \\
\text { RBK }\end{array}$ & $\begin{array}{l}30 \text { mg metimazolu + } \\
100 \mu \mathrm{g} \mathrm{L-T4}+200 \mu \mathrm{g} \\
\text { selenometioniny/dobę } \\
\text { (15 kobiet i } 4 \text { mężczyzn) } \\
30 \mathrm{mg} \text { metimazolu + } \\
100 \mu \mathrm{g} \text { L-T4/dobę } \\
\text { (16 kobiet } \\
\text { i } 3 \text { mężczyzn) } \\
\text { Brak pomiarów selenu, } \\
\text { stężenie SPP w } \\
\text { surowicy - } 47 \mathrm{ng} / \mathrm{ml} \\
\text { oraz } 49,5 \mathrm{ng} / \mathrm{ml}\end{array}$ & $\begin{array}{l}\text { Stężenia TSH, fT3, } \\
\text { fT4, aTSHR i aTPO } \\
\text { Stężenie SPP } \\
\text { w surowicy } \\
\text { Badanie dobrostanu } \\
\text { (wskaźniki depresji } \\
\text { i niepokoju) }\end{array}$ & $\begin{array}{l}\text { 1. W grupie } 1 \text { stwierdzono: } \\
\text { — znamiennie niższe wartości fT4 po } 18 \text { i } 36 \\
\text { tygodniach oraz wyższe TSH po } 18 \text { tygodniach } \\
\text { — negatywną korelację pomiędzy wskaźnikiem } \\
\text { depresji a fT3 oraz pozytywną pomiędzy w/w } \\
\text { wskaźnikiem a TSH } \\
\text { 2. Bez istotnych różnić w stężeniach aTPO i aTSHR } \\
\text { oraz wskaźnikach dobrostanu pomiędzy grupami }\end{array}$ \\
\hline
\end{tabular}


Tabela II (cd.). Krótka charakterystyka najważniejszych badań klinicznych dot. związku pomiędzy selenem a tagodnymi chorobami tarczycy

\begin{tabular}{|c|c|c|c|c|c|}
\hline $\begin{array}{l}\text { Pilli i wsp. } \\
\text { Eur Thyroid J } \\
\text { (2015) [142] }\end{array}$ & $\begin{array}{l}60 \text { kobiet } \\
\text { z PAZT, nie } \\
\text { leczonych L-T4 } \\
\text { i w eutyreozie }\end{array}$ & $\begin{array}{l}12 \text { miesięcy; } \\
\text { RBK }\end{array}$ & $\begin{array}{l}\text { Placebo }(\mathrm{n}=20) \\
80 \mu \mathrm{g} \text { selenometioniny } \\
\text { ( } \mathrm{n}=20 \text { ) } \\
160 \mu \mathrm{g} \\
\text { selenometioniny } \\
\text { ( } \mathrm{n}=20 \text { ) } \\
\text { Średnie początkowe } \\
\text { stężenie selenu } \\
\text { w surowicy - } \\
81,8 \mu \mathrm{g} / \mathrm{L}\end{array}$ & $\begin{array}{l}\text { Stężenia TSH, fT3, fT4 } \\
\text { Stężenia aTP0, aTG } \\
\text { Stężenie selenu w } \\
\text { surowicy } \\
\text { Obraz USG tarczycy } \\
\text { Stężenia wybranych } \\
\text { cytokin i chemokin } \\
\text { Jakość życia }\end{array}$ & $\begin{array}{l}\text { 1. Brak istotnych zmian w stężeniach aTPO } \\
\text { w grupach przyjmujących selen } \\
\text { 2. Znamienny spadek stężeń aTG w grupie } \\
\text { przyjmującej } 160 \mu \text { g selenu oraz placebo } \\
\text { po } 12 \text { miesiącach } \\
\text { 3. Brak istotnych zmian w obrazie USG tarczycy } \\
\text { oraz jakości życia w grupach oraz pomiędzy nimi } \\
\text { 4. Stężenia chemokin CXCL-9 i -10 uległy obniżeniu } \\
\text { po } 6 \text { i } 12 \text { miesiącach stosowania selenometioniny, } \\
\text { podczas gdy w grupie kontrolnej nie uległy zmianie }\end{array}$ \\
\hline $\begin{array}{l}\text { Farias i wsp. } \\
\text { J Endocrinol } \\
\text { Invest (2015) } \\
\text { [143] }\end{array}$ & $\begin{array}{l}55 \text { pacjentów } \\
\text { z PAZT (50 } \\
\text { kobiet i } 5 \\
\text { mężczyzn) }\end{array}$ & $\begin{array}{l}6 \text { miesięcy; } \\
\text { RBK }\end{array}$ & $\begin{array}{l}200 \mu \mathrm{g} \\
\text { selenometioniny przez } \\
3 \text { miesiące } \\
\text { (26 kobiet } \\
\text { i } 2 \text { mężczyzn) } \\
\text { Placebo przez } \\
3 \text { miesiące ( } 24 \text { kobiety } \\
\text { i } 3 \text { mężczyzn) } \\
\text { Średnie początkowe } \\
\text { stężenie selenu } \\
\text { w surowicy - brak } \\
\text { dostępu do danych }\end{array}$ & $\begin{array}{l}\text { Stężenie selenu i PG1 } \\
\text { w surowicy } \\
\text { Stężenia aTP0 } \\
\text { Obraz USG tarczycy }\end{array}$ & $\begin{array}{l}\text { Znamienny spadek stężenia aTPO po } 6 \text { miesiącach } \\
\text { obserwacji, bez analogicznych zmian w grupie } \\
\text { placebo }\end{array}$ \\
\hline $\begin{array}{l}\text { Wang i wsp. } \\
\text { Horm Metab } \\
\text { Res. (2016) } \\
\text { [144] }\end{array}$ & $\begin{array}{l}41 \text { pacjentów } \\
\text { z nawracającą } \\
\text { chorobą } \\
\text { Gravesa i } \\
\text { Basedowa } \\
\text { (34 kobiety } \\
\text { i } 7 \text { mężczyzn) }\end{array}$ & $\begin{array}{l}6 \text { miesięcy } \\
+ \text { follow-up; } \\
\text { RBK lub } \\
\text { quasi-RBK }\end{array}$ & $\begin{array}{l}\text { Metimazol (18 kobiet } \\
\text { i } 2 \text { mężczyzn) } \\
\text { Metimazol + } 200 \mu \mathrm{g} \\
\text { selenianu sodu (16 } \\
\text { kobiet i } 5 \text { mężczyzn) } \\
\text { Średnie początkowe } \\
\text { stężenie selenu } \\
\text { w surowicy — brak } \\
\text { dostępu do danych }\end{array}$ & $\begin{array}{l}\text { Stężenia TSH, fT3, } \\
\text { fT4 i aTSHR } \\
\text { Odsetek remisji }\end{array}$ & $\begin{array}{l}\text { W grupie } 2 \text { stwierdzono: } \\
\text { — znamiennie niższe fT3 i fT4 oraz wyższe TSH } \\
\text { po } 2 \text { miesiącach leczenia } \\
\text { — znamiennie niższe aTSHR po zakończeniu } \\
\text { 6-miesięcznej suplementacji (pomiar } \\
\text { na wizycie follow-up) } \\
\text { — istotnie większy odsetek normalizacji aTSHR po } \\
6 \text { miesiącach (19\% vs 0\%) } \\
\text { — znamiennie większa szansa na uzyskanie } \\
\text { remisji u pacjentów przyjmujących selen }\end{array}$ \\
\hline
\end{tabular}

PAZT — przewlekłe autoimmunologiczne zapalenie tarczycy; RBK — randomizowane badanie kliniczne; NRBK — badanie nierandomizowane — otwarte (open label); PG1 — peroksydaza glutationu 1; SPP — selenoproteina P

już wcześniej [147]. Aktualnie trwają dwa interesujące badania kliniczne [148, 149], których wyniki mogą nas przybliżyć do bardziej jednoznacznej odpowiedzi na pytanie czy suplementacja selenem istotnie wpływa na stan pacjentów z chorobą Gravesa i Basedowa [148] oraz jakość życia chorych z PAZT [149].

Selen pełni istotną rolę w utrzymaniu homeostazy ludzkiego organizmu. Selenoproteiny chronią organizm przed uszkodzeniami spowodowanymi stresem oksydacyjnym, w tym również GT i odpowiadają za jego fizjologiczne działanie i adekwatną produkcję hormonalną. Zagadnienie suplementacji selenu w celu profilaktyki pierwotnej i wtórnej rozmaitych zaburzeń strukturalnych i czynnościowych GT pozostaje wciąż kwestią otwartą i wymaga dalszych badań. Z uwagi na obiecujące dane płynące z zaprezentowanych badań klinicznych, należy rozważyć zastosowanie suplementacji w autoimmunologicznych chorobach tarczycy, w tym także rozpowszechnionej chorobie Hashimoto.
Szczególne korzyści mogą odnieść pacjenci, z populacji niedoborowej lub osoby, u których potwierdzono niedobór tego pierwiastka przeprowadzając analizę stężenia selenu w osoczu. Należałoby się zatem zastanowić nad kosztoefektywnością takiego postępowania i ewentualnym wdrożeniem takich badań do algorytmów diagnostycznych. Trzeba mieć jednak na uwadze dość wąski indeks terapeutyczny selenu oraz ryzyko związane z ostrym i przewlekłym przedawkowaniem, w szczególności zwiększone ryzyko rozwoju cukrzycy typu 2. Ze względu na zwiększone zapotrzebowanie na selen w ciąży, powinno się także rozważyć korzyści, które mogłyby płynąć z jego suplementacji w tej grupie i ewentualnie stworzyć odpowiednie zalecenia, tak jak ma to miejsce w przypadku jodu [150]. Aktualnie rekomenduje się 6 miesięczną suplementację $200 \mu \mathrm{g}$ selenu w łagodnych postaciach krótko trwającej orbitopatii tarczycowej, gdyż przynosi ona wymierne korzyści kliniczne. 